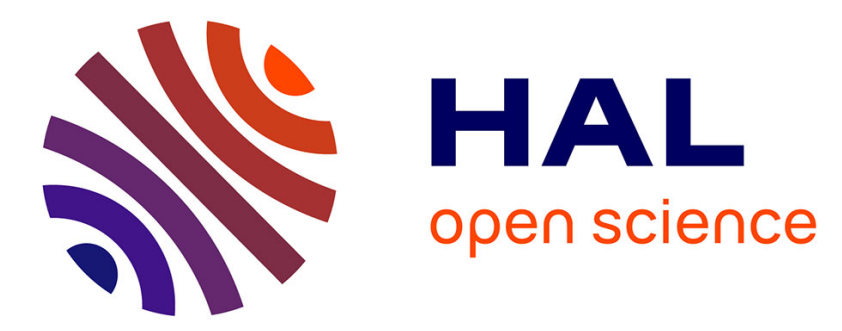

\title{
Experimental and modeling study of the oxidation of 1-butene and cis-2-butene in a jet-stirred reactor and a combustion vessel
}

\author{
Yann Fenard, Guillaume Dayma, Fabien Halter, Fabrice Foucher, Zeynep \\ Serinyel, Philippe Dagaut
}

\section{To cite this version:}

Yann Fenard, Guillaume Dayma, Fabien Halter, Fabrice Foucher, Zeynep Serinyel, et al.. Experimental and modeling study of the oxidation of 1-butene and cis-2-butene in a jet-stirred reactor and a combustion vessel. Energy \& Fuels, 2015, 29 (2), pp.1107-1118. 10.1021/ef502732c . hal-01233974

\section{HAL Id: hal-01233974 \\ https://hal.science/hal-01233974}

Submitted on 3 Jan 2022

HAL is a multi-disciplinary open access archive for the deposit and dissemination of scientific research documents, whether they are published or not. The documents may come from teaching and research institutions in France or abroad, or from public or private research centers.
L'archive ouverte pluridisciplinaire HAL, est destinée au dépôt et à la diffusion de documents scientifiques de niveau recherche, publiés ou non, émanant des établissements d'enseignement et de recherche français ou étrangers, des laboratoires publics ou privés.

\section{(ㅇ)(1) $\$$}

Distributed under a Creative Commons Attribution - NonCommerciall 4.0 International 


\title{
Experimental and Modeling Study of the Oxidation of 1-Butene and cis-2-Butene in a Jet-Stirred Reactor and a Combustion Vessel
}

\author{
Yann Fenard, ${ }^{\dagger}$ Guillaume Dayma, $^{\dagger, \ddagger}$ Fabien Halter, $^{\dagger}$ Fabrice Foucher, $^{\S}$ Zeynep Serinyel, $^{\dagger, \ddagger}$ \\ and Philippe Dagaut* ${ }^{*} \dagger$ \\ ${ }^{\dagger}$ CNRS-INSIS, 1-C Avenue de la Recherche Scientifique, 45071 Orléans cedex 2, France \\ ${ }^{\ddagger}$ Université d’Orléans, Collegium Sciences et Techniques, 1 rue de Chartres, 45067 Orléans cedex 2, France \\ ${ }^{\S}$ Laboratoire PRISME, Université d'Orléans, 45072 Orléans cedex 2, France
}

\begin{abstract}
Significant amounts of unsaturated hydrocarbons, such as butene isomers, are formed as intermediate products during the oxidation of higher hydrocarbons. In this study, new experimental data were obtained for the oxidation of 1-butene and cis-2-butene. The experiments were conducted in a jet-stirred reactor in the temperature range of $900-1440 \mathrm{~K}$, at atmospheric pressure, for different equivalence ratios $(0.25 \leq \varphi \leq 2)$, and in a combustion vessel at $p=1$ atm and unburned gas temperatures in the range of 300-450 K. From gas sampled in the jet-stirred reactor, concentration profiles of stable species were measured by gas chromatography and infrared spectrometry. A combustion vessel was used to determine laminar burning velocities of butene-air mixtures at atmospheric pressure and over the equivalence ratio range of $0.8-1.4$. Additional data were obtained over a range of pressure (1-5 atm). A detailed chemical kinetic mechanism based on a previously proposed scheme for the oxidation of hydrocarbons was used to reproduce the present experimental data (201 species involved in 1787 reactions). The present mechanism was also tested against literature data: the structure of 1-butene premixed low pressure flat flames and 1butene/oxygen/argon mixtures ignition delays were simulated, showing satisfactory agreement. Sensitivity analyses and reaction paths analyses were used to rationalize the results. Finally, the oxidations of cis-2-butene and trans-2-butene were compared and discussed.
\end{abstract}

\section{INTRODUCTION}

The oxidation of alcohols, alkanes, or esters, abundant in conventional fuels as well as in biofuels, can release large fractions of butenes. Butene is the shortest alkene with isomers: three linear isomers (1-butene, trans-2-butene, and cis-2butene) and a branched isomer (2-methylpropene or isobutene). With 4 carbon atoms, butene isomers are good candidates for upgrading detailed combustion reaction mechanisms of middle-sized species. A good understanding of their oxidation can lead to better extension of detailed mechanisms to larger alkenes.

In the past decades, several studies on the pyrolysis and oxidation of linear butenes have been performed (Table 1). Chakir et al. ${ }^{1}$ studied the oxidation of 1-butene in a jet-stirred reactor, where stable species have been measured by gas chromatography. These data were used by Heyberger et al. ${ }^{2}$ to validate a detailed kinetic mechanism of 1-butene oxidation. In addition, in that study, ${ }^{2}$ experimental ignition delays 1-butene/ $\mathrm{O}_{2} / \mathrm{Ar}$ obtained in a shock tube were provided. Davis et al. ${ }^{3}$ obtained laminar burning velocities of 1-butene in air in counter-flow burners at atmospheric pressure. Similar nonpremixed counter-flow burners were used by Zhao et al. ${ }^{4}$ for the measurement of ignition temperatures of the four isomers of butene in air between 1.5 and 5 atm. That study was completed with measurements of laminar burning velocities of 1-butene, trans-2-butene, and iso-butene in air. Zhang et al. ${ }^{5}$ studied the pyrolysis of butene isomers in a laminar flow reactor at low pressure, and products were identified and quantified using a synchrotron vacuum ultraviolet photoionization mass spectrometer. Schenk et al. ${ }^{6}$ investigated the structure of premixed flat flames of the isomers of butene $\left(\mathrm{C}_{4} \mathrm{H}_{8} / \mathrm{O}_{2} / \mathrm{Ar}\right)$ at low pressure. Concentrations of stable species and radicals in the flames were measured by molecular-beam mass spectrometry. More recently, Fenard et al. ${ }^{7}$ studied the oxidation of trans-2-butene in a jet-stirred reactor and in a combustion vessel. Stable species were quantified by GC and FTIR.

The focus of this paper is on the oxidation of 1-butene and cis-2-butene. New experimental data for the oxidation of 1butene and cis-2-butene in a JSR and a combustion vessel are presented. Also, the validation of the oxidation mechanisms for three linear butene isomers was achieved.

\section{EXPERIMENTAL SECTION}

2.1. Jet-Stirred Reactor. The apparatus used in this study was first described by Dagaut et al. ${ }^{8}$ The experimental setup was recently detailed for trans-2-butene oxidation. ${ }^{7}$ Briefly, the reactor consists in a $4 \mathrm{~cm}$ diameter fused silica sphere, for a total volume of $27.2 \mathrm{~cm}^{3}$. The admission of the reactants diluted in nitrogen $\left(<100 \mathrm{ppm} \mathrm{H}_{2} \mathrm{O},<50\right.$ ppm $\mathrm{O}_{2},<1000 \mathrm{ppm} \mathrm{Ar},<5 \mathrm{ppm}<\mathrm{H}_{2}$ ) is allowed by four nozzles of 1 $\mathrm{mm}$ inner diameter opposed in a pair, providing the stirring of gases inside the reactor. For the fuels, mixtures of $5.99( \pm 0.18) \% \mathrm{~mol}$ of 1 butene in nitrogen and $6.01( \pm 0.18) \% \mathrm{~mol}$ in nitrogen were used (Air Liquide). Oxygen was $99.995 \%$ pure. A thermocouple (0.1 mm Pt-Pt/ 
Table 1. Previous Experimental Studies on Linear Butenes Oxidation or Pyrolysis

\begin{tabular}{|c|c|c|c|c|c|}
\hline year & temperature range & pressure & reaction type & reactor & reference \\
\hline \multicolumn{6}{|c|}{ 1-butene } \\
\hline 1989 & $900-1200 \mathrm{~K}$ & $1-10 \mathrm{~atm}$ & oxidation & jet-stirred reactor & 1 \\
\hline 1998 & flame temperature & $1 \mathrm{~atm}$ & oxidation & counter-flow burner & 3 \\
\hline 2002 & $900-1200 \mathrm{~K}$ & $1-10 \mathrm{~atm}$ & oxidation & jet-stirred reactor & 2 \\
\hline 2002 & $1200-1670 \mathrm{~K}$ & $6.6-8.9 \mathrm{~atm}$ & oxidation & shock tube & 2 \\
\hline 2011 & $900-1900 \mathrm{~K}$ & $40 \mathrm{mbar}$ & pyrolysis & flow reactor & 5 \\
\hline 2012 & flame temperature & 40 mbar & oxidation & premixed laminar flame & 6 \\
\hline 2014 & ignition temperature & $1.5-5 \mathrm{~atm}$ & oxidation & counter-flow burner & 4 \\
\hline 2014 & flame temperature & $1-10 \mathrm{~atm}$ & oxidation & combustion vessel & 4 \\
\hline \multicolumn{6}{|c|}{ trans-2-butene } \\
\hline 2011 & $900-1900 \mathrm{~K}$ & 40 mbar & pyrolysis & flow reactor & 5 \\
\hline 2012 & flame temperature & 40 mbar & oxidation & premixed laminar flame & 6 \\
\hline 2014 & ignition temperature & $1.5-5 \mathrm{~atm}$ & oxidation & counter-flow burner & 4 \\
\hline 2014 & flame temperature & $1-10 \mathrm{~atm}$ & oxidation & combustion vessel & 4 \\
\hline 2014 & $900-1440 \mathrm{~K}$ & $1 \mathrm{~atm}$ & oxidation & jet-stirred reactor & 7 \\
\hline 2014 & flame temperature & $1 \mathrm{~atm}$ & oxidation & combustion vessel & 7 \\
\hline \multicolumn{6}{|c|}{ cis-2-butene } \\
\hline 2014 & $1000-1400 \mathrm{~K}$ & $1.5-5 \mathrm{~atm}$ & oxidation & counter-flow burner & 4 \\
\hline
\end{tabular}

$\mathrm{Rh}-10 \%$, located inside a thin-wall silica tube) was used to measure the temperature inside the reactor. The reactant mixture was sampled with a movable fused silica low pressure sonic probe. A Teflon line ensures the transfer of samples to the analyzers. The line is heated at $200{ }^{\circ} \mathrm{C}$, avoiding the condensation of species. An online FTIR (Nicolet 6700, 2 $\mathrm{m}$ path length, $500 \mathrm{mbar}$, and a resolution of $0.5 \mathrm{~cm}^{-1}$ ) was used to measure $\mathrm{CH}_{2} \mathrm{O}, \mathrm{H}_{2} \mathrm{O}, \mathrm{CO}$, and $\mathrm{CO}_{2}$ concentrations. Off-line analyses were also performed, after collection of samples and storage in $1 \mathrm{~L}$ Pyrex bulbs, we used gas chromatographs (GC) equipped with capillary columns (DB-624, $\mathrm{CP}-\mathrm{Al}_{2} \mathrm{O}_{3}-\mathrm{KCl}$, and Carboplot-P7), a thermal conductivity detector (TCD), and a flame ionization detector (FID). $\mathrm{O}_{2}$ and $\mathrm{H}_{2}$ were quantified with a TCD, whereas $\mathrm{CH}_{4}, \mathrm{C}_{2} \mathrm{H}_{6}$, $\mathrm{C}_{2} \mathrm{H}_{4}, \mathrm{C}_{2} \mathrm{H}_{2}, \mathrm{C}_{3} \mathrm{H}_{6}$, allene, propyne, trans- and cis-2- $\mathrm{C}_{4} \mathrm{H}_{8}, 1-\mathrm{C}_{4} \mathrm{H}_{8}, 1,3-$ $\mathrm{C}_{4} \mathrm{H}_{6}, \quad 1,2-\mathrm{C}_{4} \mathrm{H}_{6}, \quad 1-\mathrm{C}_{4} \mathrm{H}_{6}, \quad 2-\mathrm{C}_{4} \mathrm{H}_{6}$, isoprene, $\mathrm{C}_{4} \mathrm{H}_{4}, \mathrm{C}_{4} \mathrm{H}_{2}, 1,3-$ cyclopentadiene, and benzene were quantified with an FID. A GCMS (Varian V1200) operating with electron ionization (70 eV) was used for products identification. Other minor products were found: $i$ $\mathrm{C}_{4} \mathrm{H}_{8}$, 2-methyl-2-butene, 2-methyl-1-butene, 3-methyl-1-butene, t2$\mathrm{C}_{5} \mathrm{H}_{10}, c 2-\mathrm{C}_{5} \mathrm{H}_{10}, 1,3-\mathrm{C}_{5} \mathrm{H}_{8}$, and toluene. The larger products were detected by $\mathrm{GC} / \mathrm{FID}$ and $\mathrm{GC} / \mathrm{MS}$ at trace concentrations. Among them, toluene was the most abundant with a maximum detected concentration of a ppm. This is consistent with ${ }^{6}$ ([toluene $] /[$ benzene $]$ $=0.1$ ) and with our modeling. The experiments were performed at atmospheric pressure, and the reactor temperature was varied stepwise. Uncertainty on temperature measurements was estimated to be less than $10 \mathrm{~K}$, and that on residence time was less than $5 \%$. Uncertainty on reactor pressure was \pm 0.1 atm. Inlet uncertainties are less than $5 \%$ for the reactants; for measured species, an uncertainty $<10 \%$ was determined for those with concentrations higher than $10 \mathrm{ppm} .{ }^{9}$

2.2. Laminar Flame Speed Setup. The stainless steel spherical combustion chamber ${ }^{7,10}$ is $200 \mathrm{~mm}$ in inner diameter for a total volume of $4.2 \mathrm{~L}$. A resistance wire surrounds the sphere and allows a rise in temperature up to $473 \mathrm{~K}$. A vacuum pump reduces the residual pressure inside the device (checked via a piezoelectric pressure transducer) to $<0.003$ bar before reactants injection. We used the same fuel-nitrogen mixture as in JSR experiments. Due to nitrogen dilution, oxygen and nitrogen were added to get the oxygen/nitrogen ratio in air $\left(20.9 \% \mathrm{~mol}\right.$ of $\mathrm{O}_{2} / 79.1 \% \mathrm{~mol}$ of $\left.\mathrm{N}_{2}\right)$ and match the desired equivalence ratio. Homogeneity of the mixture is obtained with a fan installed inside the combustion vessel, stopped before ignition. The initial temperature of the prepared mixture was known at $\pm 2 \mathrm{~K}$ and measured with a type- $K$ thermocouple. The spark initiating the flame is produced in the center of the chamber by two tungsten electrodes with a $1 \mathrm{~mm}$ gap. An LED illuminator (HardSoft DLR IL104G) was used to provide continuous and incoherent light $(\lambda=528 \mathrm{~nm})$. The beam passes through several optical devices (an objective, a $3 \mathrm{~mm}$ pinhole, a $70 \mathrm{~mm}$ diameter plano-convex lens, and $1000 \mathrm{~mm}$ of focal length). After passing through the combustion chamber (windows diameter $=82 \mathrm{~mm}$ ), the beam is displayed on a screen. The visualization of the flame was obtained using a classical shadowgraph method. The high-speed video camera (Photron Fastcam) operates at 6000 images per second. Measurements were limited to flames with diameters $<50 \mathrm{~mm}$, corresponding to a volume of burned gases less than $1.6 \%$ of the chamber volume. Under such conditions, the total chamber pressure can be considered constant during the initial stage of flame expansion. The laminar burning velocity extraction follows the procedure used earlier. ${ }^{10}$ Since the pressure is constant, the laminar burning velocity can be approximated as $S_{u}{ }^{\circ}=S_{b}{ }^{\circ} \rho_{b} / \rho_{u}$, with $\rho_{b}$ and $\rho_{u}$ the density of burned and unburned gases. EQUIL from the CHEMKIN package ${ }^{12,13}$ was used to estimate the burned/unburned gas density ratio. From the relation between the propagation speed $S_{b}$ ( $S_{b}=\mathrm{d} R_{f} / \mathrm{d} t$ with $R_{f}$ the measured flame radius and $t$ time) and the stretch rate $\kappa\left(\kappa=2 S_{b} / R_{f}\right)$, the unstretched propagation speed $S_{b}{ }^{\circ}$ can be determined and the resulting nonlinear relation is $\left(S_{b} / S_{b}{ }^{\circ}\right)^{2} \ln \left(S_{b} /\right.$ $\left.S_{b}^{\circ}\right)^{2}=-2 L_{b} \kappa / S_{b}{ }^{\circ},{ }^{11}$ where $L_{b}$ is the burned gas Markstein length.

\section{COMPUTATIONAL METHODS}

The oxidation of 1-butene and cis-2-butene in a JSR was simulated with the subroutine PSR ${ }^{14}$ of the CHEMKIN II package. The laminar burning velocities and the premixed low pressure flat flames were computed with the subroutine PREMIX. $^{15}$ The subroutine SENKIN ${ }^{16}$ was used to simulate the ignition delays. The model inputs included the proposed detailed chemical kinetic reaction mechanism, a data set of thermochemical properties, and a data set of transport properties, the latter being optional for PSR and SENKIN modeling.

The $\mathrm{C}_{0}$ base of the mechanism used in this work is derived from the recent work of Kéromnès et al. ${ }^{17}$ The $C_{1}-C_{6}$ base is mostly from a mechanism for the oxidation of hydrocarbons, from natural gas to kerosene and diesel fuel, ${ }^{18,19}$ which contains submechanisms describing the oxidation of formaldehyde $\left(\mathrm{CH}_{2} \mathrm{O}\right)$, methanol $\left(\mathrm{CH}_{3} \mathrm{OH}\right)$, methane $\left(\mathrm{CH}_{4}\right)$, ethane $\left(\mathrm{C}_{2} \mathrm{H}_{6}\right)$, ethylene $\left(\mathrm{C}_{2} \mathrm{H}_{4}\right)$, acetylene $\left(\mathrm{C}_{2} \mathrm{H}_{2}\right)$, ethanal $\left(\mathrm{CH}_{3} \mathrm{CHO}\right)$, ethanol $\left(\mathrm{C}_{2} \mathrm{H}_{5} \mathrm{OH}\right)$, propane $\left(\mathrm{C}_{3} \mathrm{H}_{8}\right)$, propene $\left(\mathrm{C}_{3} \mathrm{H}_{6}\right)$, propanal $\left(\mathrm{C}_{2} \mathrm{H}_{5} \mathrm{CHO}\right)$, acrolein $\left(\mathrm{C}_{2} \mathrm{H}_{3} \mathrm{CHO}\right)$, acetone $\left(\mathrm{CH}_{3} \mathrm{COCH}_{3}\right)$, propyne and allene $\left(\mathrm{C}_{3} \mathrm{H}_{4}-\mathrm{P}\right.$ et $\left.\mathrm{C}_{3} \mathrm{H}_{4}-\mathrm{A}\right)$, 1butene $\left(\mathrm{C}_{4} \mathrm{H}_{8}-1\right)$, trans-2-butene $\left(\mathrm{T}_{2} \mathrm{C}_{4} \mathrm{H}_{8}\right)$ and cis-2-butene $\left(\mathrm{C} 2 \mathrm{C}_{4} \mathrm{H}_{8}\right)$, iso-butene $\left(\mathrm{IC}_{4} \mathrm{H}_{8}\right), 1,3$-butadiene $\left(\mathrm{C}_{4} \mathrm{H}_{6}\right)$, 1-butyne 
(BUTYNE), 2-butyne (BUTYN2), 1,2-butadiene $\left(\mathrm{C}_{4} \mathrm{H}_{6} 12\right)$, vinylacetylene $\left(\mathrm{C}_{4} \mathrm{H}_{4}\right)$, 1,3-butadiyne $\left(\mathrm{C}_{4} \mathrm{H}_{2}\right)$, isoprene (ISOPE), cyclopentene $\left(\mathrm{CYC}_{5} \mathrm{H}_{8}\right), 1,3$-cyclopentadiene (CPD), benzene $\left(\mathrm{C}_{6} \mathrm{H}_{6}\right)$, and toluene (TOLUENE). The model consists of 201 species involved in 1787 reactions. The subscheme of butene isomers oxidation was updated.

For 1-butene, two $\mathrm{C}-\mathrm{C}$ bond cleavage reactions are considered:

$$
\begin{aligned}
& \mathrm{C}_{3} \mathrm{H}_{5}-\mathrm{A}+\mathrm{CH}_{3}+(\mathrm{M}) \rightleftarrows \mathrm{C}_{4} \mathrm{H}_{8}-1+(\mathrm{M}) \\
& \mathrm{C}_{2} \mathrm{H}_{3}+\mathrm{C}_{2} \mathrm{H}_{5}+(\mathrm{M}) \rightleftarrows \mathrm{C}_{4} \mathrm{H}_{8}-1+(\mathrm{M})
\end{aligned}
$$

Rate constants of (1) and (2) are pressure-dependent, and are both as in the work of Zhang et al. ${ }^{5}$

Furthermore, $\mathrm{C}-\mathrm{H}$ cleavage rate constants were estimated in radical + radical recombination direction for the following reactions

$$
\begin{aligned}
& \mathrm{C}_{4} \mathrm{H}_{7} 13+\mathrm{H}(+\mathrm{M}) \rightleftarrows \mathrm{C}_{4} \mathrm{H}_{8}-1(+\mathrm{M}) \\
& \mathrm{C}_{4} \mathrm{H}_{7} 14+\mathrm{H}(+\mathrm{M}) \rightleftarrows \mathrm{C}_{4} \mathrm{H}_{8}-1(+\mathrm{M}) \\
& \mathrm{C}_{4} \mathrm{H}_{7} 12+\mathrm{H} \rightleftarrows \mathrm{C}_{4} \mathrm{H}_{8}-1
\end{aligned}
$$

where $\mathrm{C}_{4} \mathrm{H}_{7} 13$ is but-1-en-3-yl, $\mathrm{C}_{4} \mathrm{H}_{7} 14$ is but-1-en-4-yl, and $\mathrm{C}_{4} \mathrm{H}_{7} 12$ is but-1-en-2-yl.

The fourth possibility, $\mathrm{C}_{4} \mathrm{H}_{7} 11+\mathrm{H} \rightleftarrows \mathrm{C}_{4} \mathrm{H}_{8}-1$, due to the position of the eliminated $\mathrm{H}$ leading to the but-1-en-1-yl radical $\left(\mathrm{C}_{4} \mathrm{H}_{7} 11\right)$, is highly unfavored and is consequently not considered in our mechanism. The pressure-dependent rate constant of the reaction (3) is adapted from the rate constant of $\mathrm{C}_{3} \mathrm{H}_{5}-\mathrm{A}+\mathrm{H}(+\mathrm{M}) \rightleftarrows \mathrm{C}_{3} \mathrm{H}_{6}(+\mathrm{M})$ calculated by Metcalfe et al. $^{22}$ The rate constant of reaction (4) used in the mechanism is based on the rate constant of $n \mathrm{C}_{3} \mathrm{H}_{7}+\mathrm{H}(+\mathrm{M}) \rightleftarrows \mathrm{C}_{3} \mathrm{H}_{8}$ $(+\mathrm{M}) .{ }^{21}$ Reaction (5) was estimated by Zhang et al. ${ }^{5}$

Several ipso reactions were also added to the mechanism

$$
\begin{aligned}
& \mathrm{C}_{4} \mathrm{H}_{8}-1+\mathrm{H} \rightleftarrows \mathrm{C}_{2} \mathrm{H}_{4}+\mathrm{C}_{2} \mathrm{H}_{5} \\
& \mathrm{C}_{4} \mathrm{H}_{8}-1+\mathrm{O} \rightleftarrows \mathrm{C}_{3} \mathrm{H}_{6}+\mathrm{CH}_{2} \mathrm{O} \\
& \mathrm{C}_{4} \mathrm{H}_{8}-1+\mathrm{O} \rightleftarrows \mathrm{CH}_{3} \mathrm{CHO}+\mathrm{C}_{2} \mathrm{H}_{4} \\
& \mathrm{C}_{4} \mathrm{H}_{8}-1+\mathrm{OH} \rightleftarrows \mathrm{C}_{2} \mathrm{H}_{5} \mathrm{CHO}+\mathrm{CH}_{3} \\
& \mathrm{C}_{4} \mathrm{H}_{8}-1+\mathrm{OH} \rightleftarrows n \mathrm{C}_{3} \mathrm{H}_{7}+\mathrm{CH}_{2} \mathrm{O}
\end{aligned}
$$

The rate constant used for reaction (6) is based on that proposed by Miller and Klippenstein ${ }^{23}$ for the reaction $\mathrm{C}_{3} \mathrm{H}_{6}+$ $\mathrm{H} \rightleftarrows \mathrm{C}_{2} \mathrm{H}_{4}+\mathrm{CH}_{3}$. Chakir et al. ${ }^{1}$ considered addition of oxygen biradical on the double bond, giving epoxides that, at considered temperatures, decompose rapidly, via reactions (7) and (8). Rate constants of reactions (9) and (10) are equivalent to those of 1-pentene $+\mathrm{OH} \rightleftarrows \mathrm{C}_{3} \mathrm{H}_{7} \mathrm{CHO}+\mathrm{CH}_{3}$ and 1pentene $+\mathrm{OH} \rightleftarrows p \mathrm{C}_{4} \mathrm{H}_{9}+\mathrm{CH}_{2} \mathrm{O}$ estimated by Touchard et al. ${ }^{24}$ For the bimolecular initiation reaction $\mathrm{C}_{4} \mathrm{H}_{8}-1+\mathrm{O}_{2} \rightleftarrows$ $\mathrm{C}_{4} \mathrm{H}_{7} 13+\mathrm{HO}_{2}$, we used the rate constant proposed by Metcalfe et al. ${ }^{25}$ Finally, 1-butene propagation reactions proceed through $\mathrm{H}$-atom abstraction: ${ }^{24,25}$

$$
\begin{aligned}
& \mathrm{C}_{4} \mathrm{H}_{8}-1+\mathrm{X} \rightleftarrows \mathrm{C}_{4} \mathrm{H}_{7} 11+\mathrm{HX} \quad \mathrm{X}=\mathrm{H} ; \mathrm{OH} ; \mathrm{O} ; \mathrm{CH}_{3} \\
& \mathrm{C}_{4} \mathrm{H}_{8}-1+\mathrm{X} \rightleftarrows \mathrm{C}_{4} \mathrm{H}_{7} 12+\mathrm{HX} \quad \mathrm{X}=\mathrm{H} ; \mathrm{OH} ; \mathrm{O} ; \mathrm{CH}_{3}
\end{aligned}
$$

$$
\begin{aligned}
& \mathrm{C}_{4} \mathrm{H}_{8}-1+\mathrm{X} \rightleftarrows \mathrm{C}_{4} \mathrm{H}_{7} 13+\mathrm{HX} \\
& \mathrm{X}=\mathrm{H} ; \mathrm{OH} ; \mathrm{O} ; \mathrm{CH}_{3} ; \mathrm{HO}_{2} ; \mathrm{C}_{2} \mathrm{H}_{3} ; \mathrm{CH}_{3} \mathrm{O} ; \mathrm{CH}_{3} \mathrm{O}_{2} ; \\
& \mathrm{C}_{3} \mathrm{H}_{5}-\mathrm{A} \\
& \mathrm{C}_{4} \mathrm{H}_{8}-1+\mathrm{X} \rightleftarrows \mathrm{C}_{4} \mathrm{H}_{7} 14+\mathrm{HX} \\
& \mathrm{X}=\mathrm{H} ; \mathrm{OH} ; \mathrm{O} ; \mathrm{CH}_{3} ; \mathrm{HO}_{2} ; \mathrm{C}_{2} \mathrm{H}_{3} ; \mathrm{CH}_{3} \mathrm{O} ; \mathrm{CH}_{3} \mathrm{O}_{2} ; \\
& \mathrm{C}_{3} \mathrm{H}_{5}-\mathrm{A}
\end{aligned}
$$

cis-2-Butene easily isomerizes to trans-2-butene and is subject to a 1,4-hydrogen elimination, leading to the formation of 1,3butadiene. ${ }^{26}$ Except for these two reactions, reaction pathways of cis-2-butene and trans-2-butene are closely coupled. Thus, rate constants for the reactions involving cis-2-butene are considered equal to those used for trans-2-butene. The reactions describing the oxidation of trans-2-butene were discussed previously. ${ }^{7}$ Briefly, for the main improvements from the original mechanism

$$
\begin{aligned}
& \mathrm{T}_{2} \mathrm{C}_{4} \mathrm{H}_{8}, \mathrm{C}_{2} \mathrm{C}_{4} \mathrm{H}_{8} \rightleftarrows \mathrm{C}_{3} \mathrm{H}_{5}-\mathrm{A}+\mathrm{CH}_{3} \\
& \mathrm{~T} 2 \mathrm{C}_{4} \mathrm{H}_{8}, \mathrm{C}_{2} \mathrm{C}_{4} \mathrm{H}_{8}+\mathrm{H} \rightleftarrows \mathrm{C}_{3} \mathrm{H}_{6}+\mathrm{CH}_{3} \\
& \mathrm{~T} 2 \mathrm{C}_{4} \mathrm{H}_{8}, \mathrm{C}_{2} \mathrm{C}_{4} \mathrm{H}_{8} \rightleftarrows \mathrm{C}_{4} \mathrm{H}_{7} 13+\mathrm{H}
\end{aligned}
$$

The rate constant for (11) is adapted from ref 5, where $\mathrm{C}_{3} \mathrm{H}_{5}$-A stands for prop-1-en-3-yl. Rate constants for $\mathrm{T}_{2} \mathrm{C}_{4} \mathrm{H}_{8}$, $\mathrm{C}_{2} \mathrm{C}_{4} \mathrm{H}_{8} \rightleftarrows \mathrm{C}_{3} \mathrm{H}_{5}-\mathrm{S}+\mathrm{CH}_{3}$ were set as analogous to $\mathrm{C}_{3} \mathrm{H}_{6} \rightleftarrows$ $\mathrm{C}_{2} \mathrm{H}_{3}+\mathrm{CH}_{3}$ proposed by Tsang, ${ }^{20}$ where the pre-exponential factor is doubled to account for the two reaction sites in 2butene $\left(\mathrm{C}_{3} \mathrm{H}_{5}-\mathrm{S}\right.$ is prop-1-en-1-yl). Also, the rate constant used for $\mathrm{C}_{3} \mathrm{H}_{6}+\mathrm{H} \rightleftarrows \mathrm{C}_{2} \mathrm{H}_{4}+\mathrm{CH}_{3}{ }^{23}$ is increased by a factor of 2 in order to describe the kinetics of (12). The rate constant for the H-elimination reaction (13) is taken as equivalent to that of $\mathrm{C}_{3} \mathrm{H}_{6}(+\mathrm{M}) \rightleftarrows \mathrm{C}_{3} \mathrm{H}_{5}-\mathrm{A}+\mathrm{H}(+\mathrm{M})^{22}$ and produces the resonantly stabilized $\mathrm{C}_{4} \mathrm{H}_{7} 13$ radical. $\mathrm{H}$-atom abstraction reactions with radicals $\mathrm{X}$ present in the environment occur through the schemes

$$
\begin{aligned}
& \mathrm{T}_{2} \mathrm{C}_{4} \mathrm{H}_{8}, \mathrm{C} 2_{4} \mathrm{C}_{4} \mathrm{H}_{8}+\mathrm{X} \rightleftarrows \mathrm{C}_{4} \mathrm{H}_{7} 13+\mathrm{HX} \\
& \mathrm{X}=\mathrm{H}, \mathrm{O}, \mathrm{OH}, \mathrm{HO}_{2}, \mathrm{CH}_{3}{ }^{27} \\
& \mathrm{~T}_{2} \mathrm{C}_{4} \mathrm{H}_{8}, \mathrm{C}_{2} \mathrm{C}_{4} \mathrm{H}_{8}+\mathrm{X} \rightleftarrows \mathrm{C}_{4} \mathrm{H}_{7} 22+\mathrm{HX} \\
& \mathrm{X}=\mathrm{H}, \mathrm{O}, \mathrm{OH}, \mathrm{HO}_{2}, \mathrm{CH}_{3}{ }^{24}
\end{aligned}
$$

Rate constants of the oxidation of butenyl radicals, produced by 1-butene as well as 2-butene, are consistent with those used previously to model the oxidation of larger hydrocarbons. ${ }^{18}$

\section{RESULTS AND DISCUSSION}

4.1. Jet-Stirred Reactor. The present study provides new experimental data on the oxidation of 1-butene and cis-2-butene in a jet-stirred reactor at a constant residence time of $\tau=70 \mathrm{~ms}$. At the lowest experimental temperature $(900 \mathrm{~K})$, the fuel is not converted, and for the highest temperatures, the fuel is totally consumed and most intermediates are highly converted. The oxidation of both fuels was studied at four equivalence ratios $(0.25,0.5,1$, and 2$)$, and the concentration of fuel injected was $1000 \mathrm{ppm}$. The carbon balance was found to be $100 \pm 10 \%$. Moreover, a good repeatability in measured mole fraction was observed. 

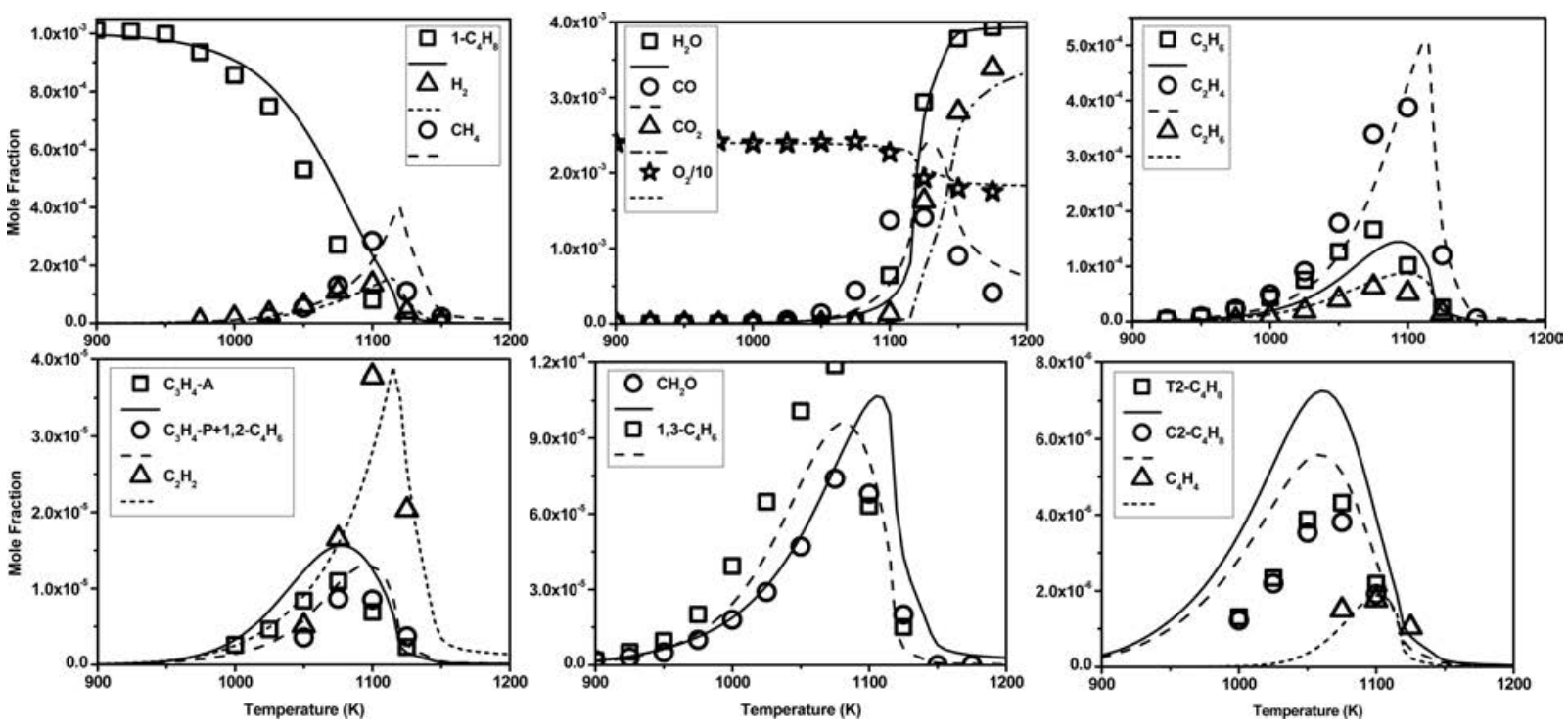

Figure 1. Experimental (symbols) and computed (lines) concentration profiles obtained from oxidation of 1-butene in a JSR at $\varphi=0.25, p=1$ atm, $\tau=70 \mathrm{~ms}$.
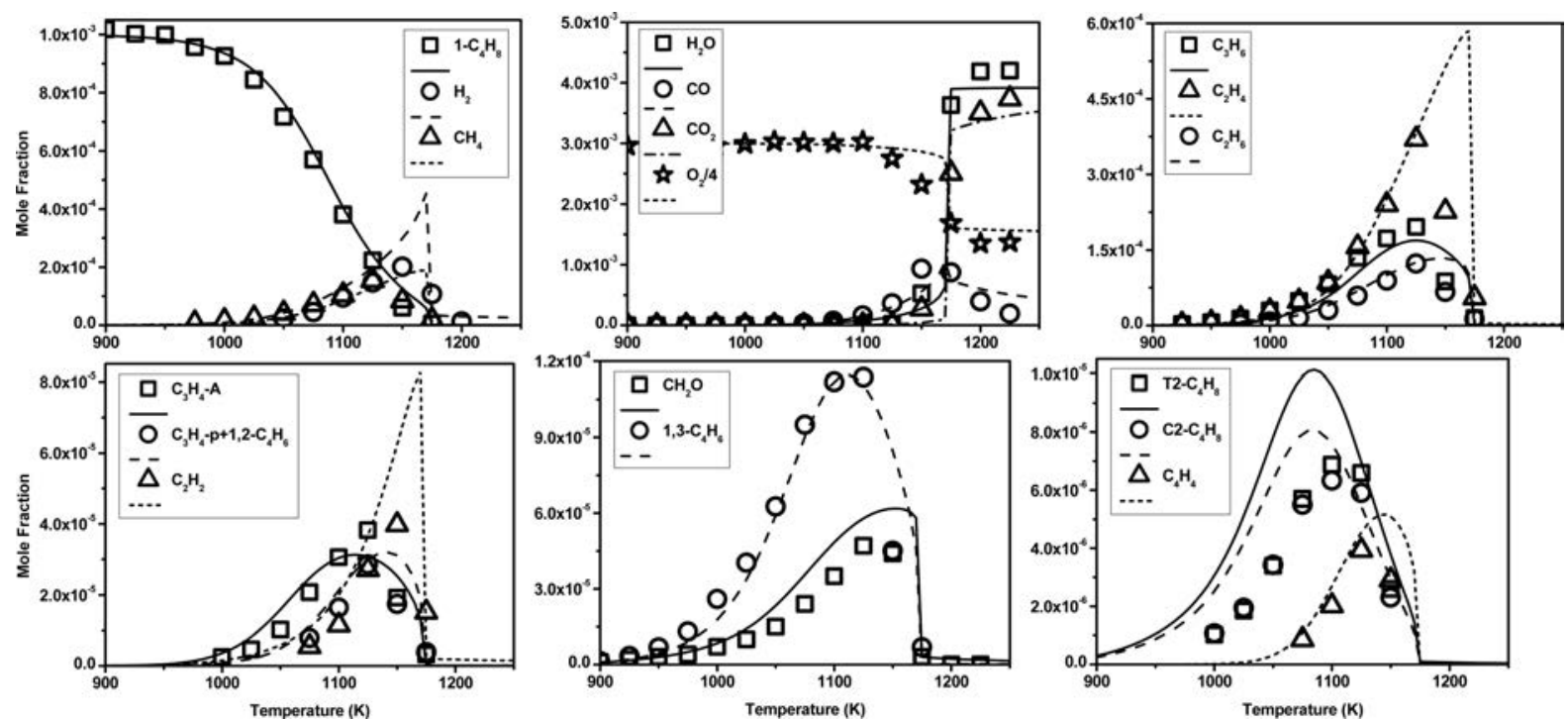

Figure 2. Experimental (symbols) and computed (lines) concentration profiles obtained from oxidation of 1-butene in a JSR at $\varphi=0.5, p=1$ atm, $\tau$ $=70 \mathrm{~ms}$.

4.1.1. 1-Butene Oxidation. Figures $1-4$ show that 1-butene reacts at temperatures higher than $950 \mathrm{~K}$ for $\varphi=0.25$ and 1000 $\mathrm{K}$ for $\varphi=0.5,1$, and 2 . The temperature interval, between the beginning of conversion and the entire conversion of 1-butene, is ca. $200 \mathrm{~K}$. In that temperature window, intermediates are accumulated, and as the temperature at which 1-butene is totally converted is reached, a dramatic decrease in intermediates' concentration is observed. The major intermediates observed experimentally are 1,3-butadiene, propene, allene, propyne, ethane, ethylene, acetylene, formaldehyde, methane, and hydrogen. Carbon monoxide accumulates until it is converted into carbon dioxide. The concentration of usual combustion products, $\mathrm{CO}_{2}$ and $\mathrm{H}_{2} \mathrm{O}$, increases dramatically as the fuel is entirely converted at $T<1250 \mathrm{~K}$. Some other minor species were identified and quantified, i.e., benzene, 1-butyne, 1-butene, and vinylacetylene. Traces amount of iso-butene, 1,3cyclopentadiene, and diacetylene were observed during the experiments.
As is usually observed for the oxidation of hydrocarbons, a decrease in the equivalence ratio causes an increase in the reactivity.

In order to illustrate the reaction pathways for the oxidation of 1-butene in a JSR, a flux analysis was performed by computing rates of formation and consumption for every species (Figure 5). The thickness of arrows depicting the reaction paths of species is proportional to the rates of consumption. The temperature of $1100 \mathrm{~K}$ was chosen such as about $50 \%$ of the fuel is converted in our conditions $(p=1 \mathrm{~atm}$, $\tau=70 \mathrm{~ms}$, and $\varphi=1)$. The model predicts that $41 \%$ of 1 butene decomposes through the reaction $1-\mathrm{C}_{4} \mathrm{H}_{8}(+\mathrm{M}) \rightleftarrows$ $\mathrm{C}_{3} \mathrm{H}_{5}-\mathrm{A}+\mathrm{CH}_{3}(+\mathrm{M})$, producing the resonantly stabilized allyl radical, mainly leading to the formation of allene and propene. Addition of $\mathrm{H}$ atom on the double bond of 1-butene occurs and produces two butyl radicals, namely, but-1-yl $\left(p \mathrm{C}_{4} \mathrm{H}_{9}, 5.2 \%\right)$ and but-2-yl $\left(s \mathrm{C}_{4} \mathrm{H}_{9}, 10.0 \%\right) \cdot p \mathrm{C}_{4} \mathrm{H}_{9}$ entirely decomposes into $\mathrm{C}_{2} \mathrm{H}_{4}$ and $\mathrm{C}_{2} \mathrm{H}_{5}$, whereas $s \mathrm{C}_{4} \mathrm{H}_{9}$ completely turns into propene 

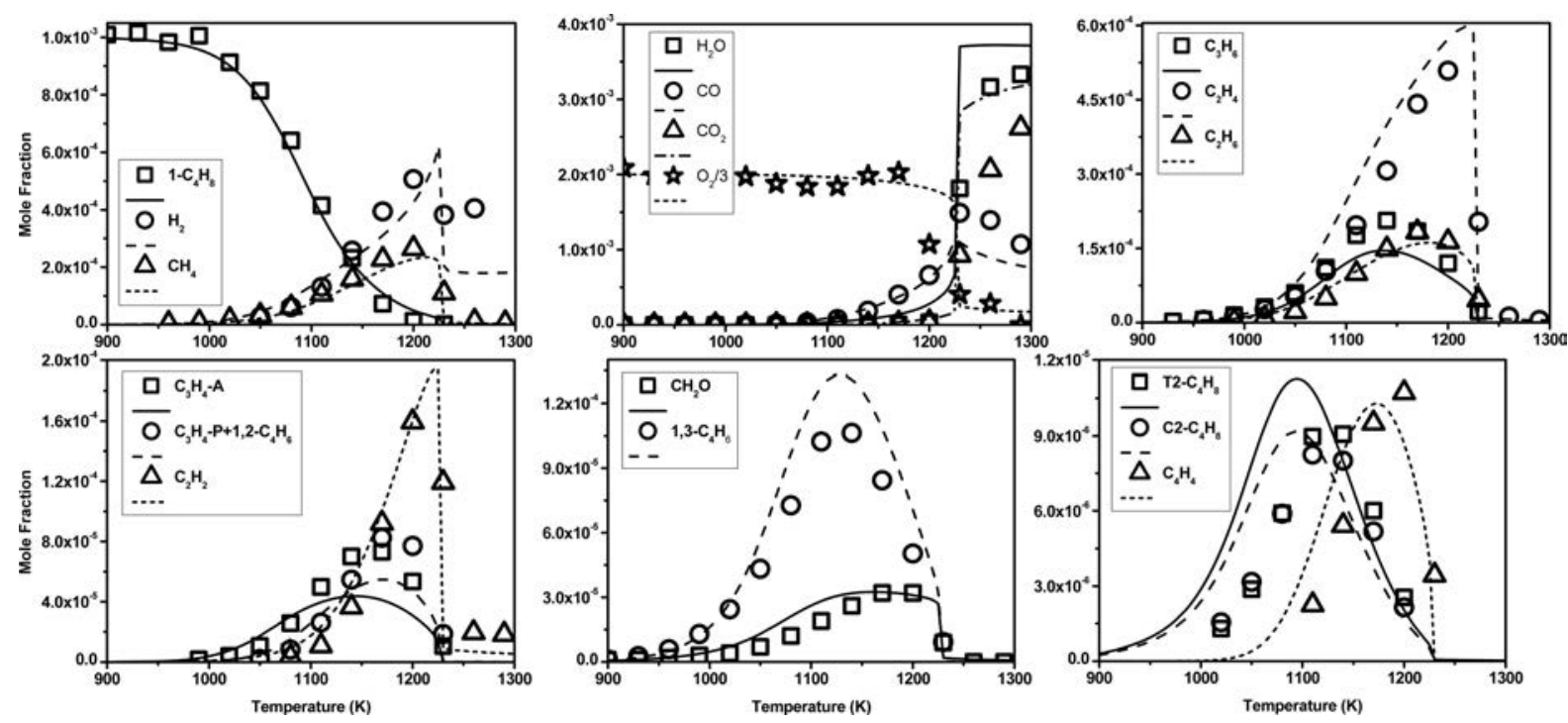

Figure 3. Experimental (symbols) and computed (lines) concentration profiles obtained from oxidation of 1-butene in a JSR at $\varphi=1, p=1$ atm, $\tau=$ $70 \mathrm{~ms}$.
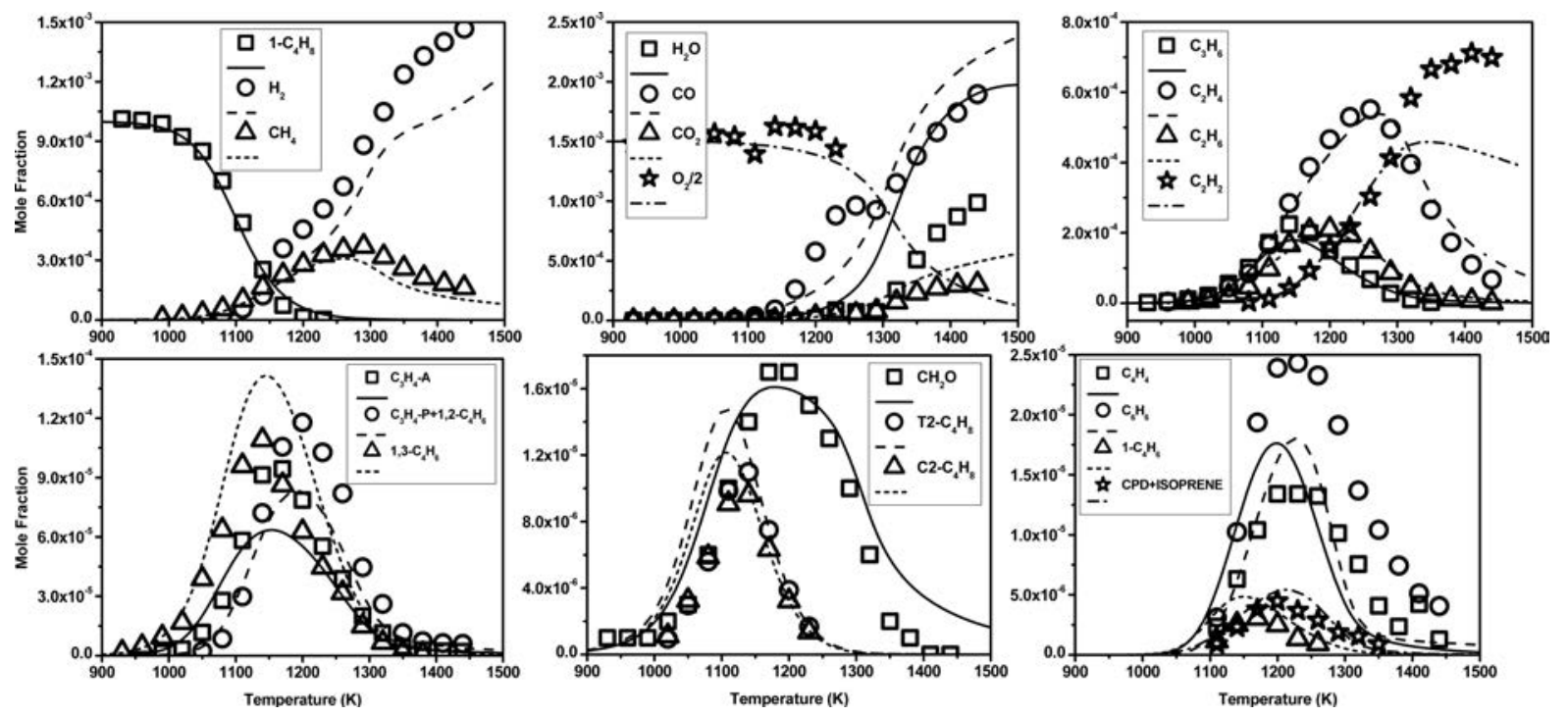

Figure 4. Experimental (symbols) and computed (lines) concentration profiles obtained from oxidation of 1-butene in a JSR at $\varphi=2, p=1 \mathrm{~atm}, \tau=$ $70 \mathrm{~ms}$.

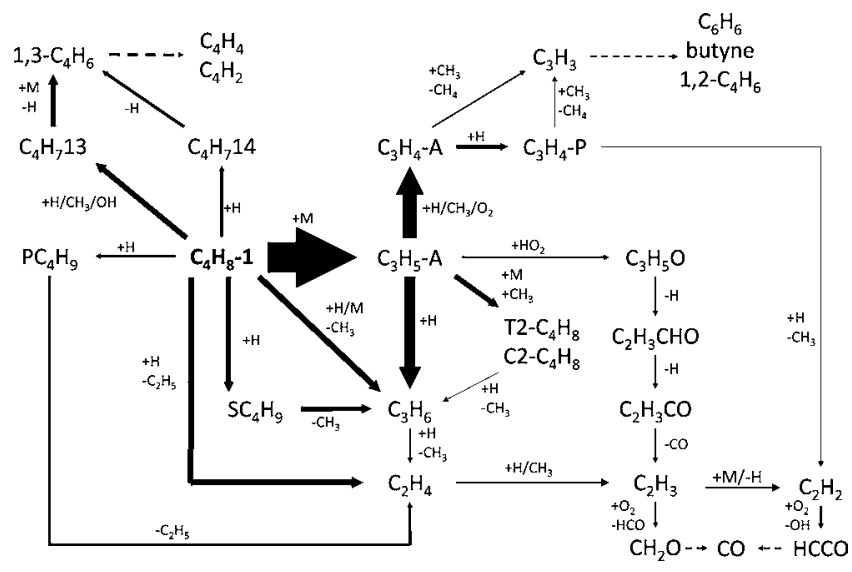

Figure 5. Reaction paths of 1-butene oxidation in a JSR at $\varphi=1, p=1$ atm, $\tau=70 \mathrm{~ms}$, and $T=1100 \mathrm{~K}$. and methyl radical. The ipso reaction $\mathrm{C}_{4} \mathrm{H}_{8}-1+\mathrm{H}=\mathrm{C}_{2} \mathrm{H}_{4}+$ $\mathrm{C}_{2} \mathrm{H}_{5}$ is responsible for $12 \%$ of the conversion of 1 -butene. Propagation reaction proceeding through $\mathrm{H}$-atom abstraction by radicals yields $\mathrm{C}_{4} \mathrm{H}_{7} 14$ (5.7\%) and with radicals $\mathrm{H}, \mathrm{OH}$, and $\mathrm{CH}_{3}$ give $\mathrm{C}_{4} \mathrm{H}_{7} 13$ (8.6\%). Both butenyl radicals lead to 1,3butadiene by $\mathrm{H}$ elimination. 1,3-Butadiene further reacts to form vinylacetylene and diacetylene, experimentally observed, especially under fuel-rich conditions (Figure 4). Allyl and methyl radicals recombine and form trans-2-butene and cis-2butene (11). 2-Butenes decompose through an ipso reaction with $\mathrm{H}$ giving propene and methyl radical (12). Propyne directly comes from allene through isomerization (33.2\%) and reaction with $\mathrm{H}$ atom, $\mathrm{C}_{3} \mathrm{H}_{4}-\mathrm{A}+\mathrm{H} \rightleftarrows \mathrm{C}_{3} \mathrm{H}_{4}-\mathrm{P}+\mathrm{H}$ (59.2\%). Allene and propyne undergo $\mathrm{H}$ abstraction by methyl radicals, yielding a propargyl radical $\left(\mathrm{C}_{3} \mathrm{H}_{3}\right)$. Propargyl radicals recombine with themselves and with methyl radicals to yield different experimentally observed species such as benzene (14), 1,2-butadiene (15), and 1-butyne (16). 


$$
\begin{aligned}
& \mathrm{C}_{3} \mathrm{H}_{3}+\mathrm{C}_{3} \mathrm{H}_{3} \rightleftarrows \mathrm{C}_{6} \mathrm{H}_{6} \\
& \mathrm{C}_{3} \mathrm{H}_{3}+\mathrm{CH}_{3} \rightleftarrows \mathrm{C}_{4} \mathrm{H}_{6} 12 \\
& \mathrm{C}_{3} \mathrm{H}_{3}+\mathrm{CH}_{3} \rightleftarrows \text { BUTYNE }
\end{aligned}
$$

Acrolein was not measured in this study. Our simulations suggest that it is produced via the sequence of reactions

$$
\begin{aligned}
& \mathrm{C}_{3} \mathrm{H}_{5}-\mathrm{A}+\mathrm{HO}_{2} \rightleftarrows \mathrm{C}_{3} \mathrm{H}_{5} \mathrm{O}+\mathrm{OH} \\
& \mathrm{C}_{3} \mathrm{H}_{5} \mathrm{O} \rightleftarrows \mathrm{C}_{2} \mathrm{H}_{3} \mathrm{CHO}+\mathrm{H}
\end{aligned}
$$

and consumed through

$$
\begin{aligned}
& \mathrm{C}_{2} \mathrm{H}_{3} \mathrm{CHO} \rightleftarrows \mathrm{C}_{2} \mathrm{H}_{4}+\mathrm{CO} \\
& \mathrm{C}_{2} \mathrm{H}_{3} \mathrm{CHO}+\mathrm{X} \rightleftarrows \mathrm{XH}+\mathrm{C}_{2} \mathrm{H}_{3} \mathrm{CO} \quad \mathrm{X}=\mathrm{H}, \mathrm{OH}, \mathrm{CH}_{3} \\
& \mathrm{C}_{2} \mathrm{H}_{3} \mathrm{CO}+\mathrm{M} \rightleftarrows \mathrm{C}_{2} \mathrm{H}_{3}+\mathrm{CO}+\mathrm{M}
\end{aligned}
$$

Under the conditions of the reaction pathway analysis, propene accumulates, but still a small amount reacts by addition with $\mathrm{H}$, yielding $\mathrm{C}_{2} \mathrm{H}_{4}$ and $\mathrm{CH}_{3} \cdot \mathrm{C}_{2} \mathrm{H}_{4}$ undergoes $\mathrm{H}$ atom abstraction, yielding the vinyl radical that further reacts to form acetylene, or formaldehyde. The large proportion of acetylene observed is due to the $\mathrm{H}$ addition on propyne also producing a methyl radical.

A sensitivity analysis to the concentration of 1-butene was performed under the conditions selected for the reaction pathway analysis presented in Figure 5 to interpret the results (Figure 6). In our mechanism, the kinetics of oxidation of 1-

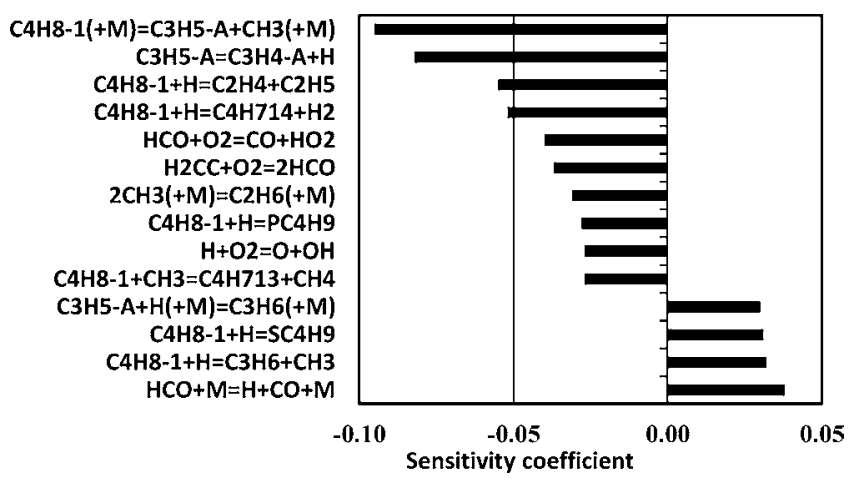

Figure 6. Sensitivity coefficients on the concentration of 1-butene obtained for the oxidation of 1-butene in a jet-stirred reactor at $\varphi=1$, $p=1 \mathrm{~atm}, \tau=70 \mathrm{~ms}$, and $T=1100 \mathrm{~K}$. C4H8-1 = 1-butene; $44 \mathrm{H} 6=$ 1,3-butadiene; PC4H9 = but-1-yl; SC4H9 = but-2-yl; C4H713 = but1-en-3-yl; C4H714 = but-1-en-4-yl; C3H6 = propene; C3H5-A = allyl radical; $\mathrm{C} 3 \mathrm{H} 4-\mathrm{A}=$ allene; $\mathrm{C} 3 \mathrm{H} 4-\mathrm{P}=$ propyne; $\mathrm{C} 2 \mathrm{H} 5$ = ethyl radical; $\mathrm{H} 2 \mathrm{CC}=$ ethen-1,1-diyl.

butene in a JSR is driven by the thermal decomposition of 1butene $\mathrm{C}_{4} \mathrm{H}_{8}-1(+\mathrm{M}) \rightleftarrows \mathrm{C}_{3} \mathrm{H}_{5}-\mathrm{A}+\mathrm{CH}_{3}(+\mathrm{M})$. Reactions of addition of the $\mathrm{H}$ atom on the double bond of 1-butene, leading to the dissociation of an adduct, are sensitive. The reaction $\mathrm{C}_{4} \mathrm{H}_{8}-1+\mathrm{H} \rightleftarrows \mathrm{C}_{2} \mathrm{H}_{5}+\mathrm{C}_{2} \mathrm{H}_{4}$ increases the overall reactivity, whereas $\mathrm{C}_{4} \mathrm{H}_{8}-1+\mathrm{H} \rightleftarrows \mathrm{C}_{3} \mathrm{H}_{6}+\mathrm{CH}_{3}$ decreases it, due to the propensity of propene to form the resonantly stabilized allyl radical. Sensitive reactions of consumption of the allyl radical have an impact on the concentration of 1-butene, $\mathrm{C}_{3} \mathrm{H}_{5}-\mathrm{A} \rightleftarrows \mathrm{C}_{3} \mathrm{H}_{4}-\mathrm{A}+\mathrm{H}$ and $\mathrm{C}_{3} \mathrm{H}_{5}-\mathrm{A}+\mathrm{H}(+\mathrm{M}) \rightleftarrows \mathrm{C}_{3} \mathrm{H}_{6}(+\mathrm{M})$. Obviously, reactions yielding allyl radicals decrease reactivity due to the accumulation of this stable species in the system. Although $\mathrm{C}_{4} \mathrm{H}_{8}-1+\mathrm{H} \rightleftarrows s \mathrm{C}_{4} \mathrm{H}_{9}$ consumes 1-butene, it inhibits the overall reactivity through the production of but-2-yl radical, which, in turn, dissociates into propene that will yield allyl and methyl radicals.

4.1.2. Cis-2-butene Oxidation. The oxidation of cis-2-butene was studied in a JSR under the conditions used to study the oxidation of 1-butene. The conversion of cis-2-butene can be observed for temperatures above $925 \mathrm{~K}$ (Figures 7-10). The major intermediates observed experimentally are trans-2butene, 1,3-butadiene, propene, allene, propyne, ethane, ethylene, acetylene, formaldehyde, methane, and hydrogen. The concentration of usual combustion products, $\mathrm{CO}, \mathrm{CO}_{2}$, and $\mathrm{H}_{2} \mathrm{O}$, increases dramatically as the fuel is entirely converted at $T<1250 \mathrm{~K}$. Some other minor species were identified and quantified, i.e., benzene, 1-butyne, 1-butene, and vinylacetylene. Trace amounts of iso-butene, 1,3-cyclopentadiene, and diacetylene were observed during the experiments. In order to obtain an overview of the oxidation scheme of cis-2-butene in a JSR, a reaction pathway analysis was performed at $\varphi=1, \tau=$ $70 \mathrm{~ms}$, and $p=1$. The temperature was set at the point where the peak of production of 1,3-butadiene, propene, and allene is observed (Figure 11). From the reaction pathway analysis, we could identify the main oxidation routes of cis-2-butene:

$$
\begin{aligned}
& \mathrm{C} 2 \mathrm{C}_{4} \mathrm{H}_{8} \rightleftarrows \mathrm{T} 2 \mathrm{C}_{4} \mathrm{H}_{8} \\
& \mathrm{C} 2 \mathrm{C}_{4} \mathrm{H}_{8} \rightleftarrows \mathrm{C}_{4} \mathrm{H}_{6}+\mathrm{H}_{2} \\
& \mathrm{C} 2 \mathrm{C}_{4} \mathrm{H}_{8} \rightleftarrows \mathrm{C}_{3} \mathrm{H}_{5}-\mathrm{A}+\mathrm{CH}_{3} \\
& \mathrm{C} 2 \mathrm{C}_{4} \mathrm{H}_{8}+\mathrm{X} \rightleftarrows \mathrm{C}_{4} \mathrm{H}_{7} 13+\mathrm{XH} \quad \mathrm{X}=\mathrm{H}, \mathrm{OH}, \mathrm{CH}_{3} \\
& \mathrm{C} 2 \mathrm{C}_{4} \mathrm{H}_{8}+\mathrm{H} \rightleftarrows \mathrm{C}_{3} \mathrm{H}_{6}+\mathrm{CH}_{3}
\end{aligned}
$$

cis-2-Butene obviously easily isomerizes into trans-2-butene (17), accounting for $47.9 \%$ of the normalized rate of consumption of cis-2-butene. Oxidation pathways of trans-2butene were already discussed in a previous work. ${ }^{7}$ cis-2-Butene is subject to 1,4-hydrogen elimination (18), yielding 1,3butadiene $(14.1 \%)$. The reaction (19) of $\mathrm{C}-\mathrm{C}$ bond cleavage is responsible for $7.5 \%$ of the cis-2-butene conversion, giving allyl and methyl radicals. $\mathrm{H}$-atom abstraction reactions (20) produce but-1-en-3-yl radicals (10.9\%). $\mathrm{C}_{4} \mathrm{H}_{7} 13$ undergoes $\mathrm{H}$ elimination, yielding 1,3-butadiene. This reaction $\left(\mathrm{C}_{4} \mathrm{H}_{7} 13(+\mathrm{M}) \rightleftarrows\right.$ $\left.\mathrm{C}_{4} \mathrm{H}_{6}+\mathrm{H}(+\mathrm{M})\right)$ and reaction (18) are responsible for $54.7 \%$ and $43.3 \%$ of 1,3-butadiene production, respectively. The ipso reaction (21) leads to the formation of propene and methyl radical (14.7\%). 1-Butene, observed experimentally with concentrations around $10 \mathrm{ppm}(\varphi=2)$, is produced by recombination of allyl and methyl radicals:

$$
\mathrm{C}_{3} \mathrm{H}_{5}-\mathrm{A}+\mathrm{CH}_{3}(+\mathrm{M}) \rightleftarrows \mathrm{C}_{4} \mathrm{H}_{8}-1(+\mathrm{M})
$$

Allene is mostly formed by $\mathrm{H}$ elimination from allyl radical. Allene isomerizes into propyne $(51.1 \%)$ via $\mathrm{C}_{3} \mathrm{H}_{4}-\mathrm{A} \rightleftarrows \mathrm{C}_{3} \mathrm{H}_{4}-\mathrm{P}$. The reaction $\mathrm{C}_{3} \mathrm{H}_{4}-\mathrm{A}+\mathrm{H} \rightleftarrows \mathrm{C}_{3} \mathrm{H}_{4}-\mathrm{P}+\mathrm{H}$ contributes to allene conversion (29.8\%). Allene and propyne, via $\mathrm{H}$-atom abstraction by methyl radicals, produce propargyl radicals, which recombine to give benzene. Vinylacetylene and diacetylene are mainly produced via the sequence

$$
\begin{gathered}
\mathrm{C}_{4} \mathrm{H}_{6}+\mathrm{X} \stackrel{-\mathrm{HX}}{\rightleftarrows} i \mathrm{C}_{4} \mathrm{H}_{5} \stackrel{-\mathrm{H}}{\rightleftarrows} \mathrm{C}_{4} \mathrm{H}_{4} \stackrel{-\mathrm{H}_{2}}{\rightleftarrows} \mathrm{C}_{4} \mathrm{H}_{2} \\
\mathrm{X}=\mathrm{O}, \mathrm{OH}, \mathrm{CH}_{3}
\end{gathered}
$$

where $i \mathrm{C}_{4} \mathrm{H}_{5}$ stands for the radical buta-1,3-dien-2-yl. 

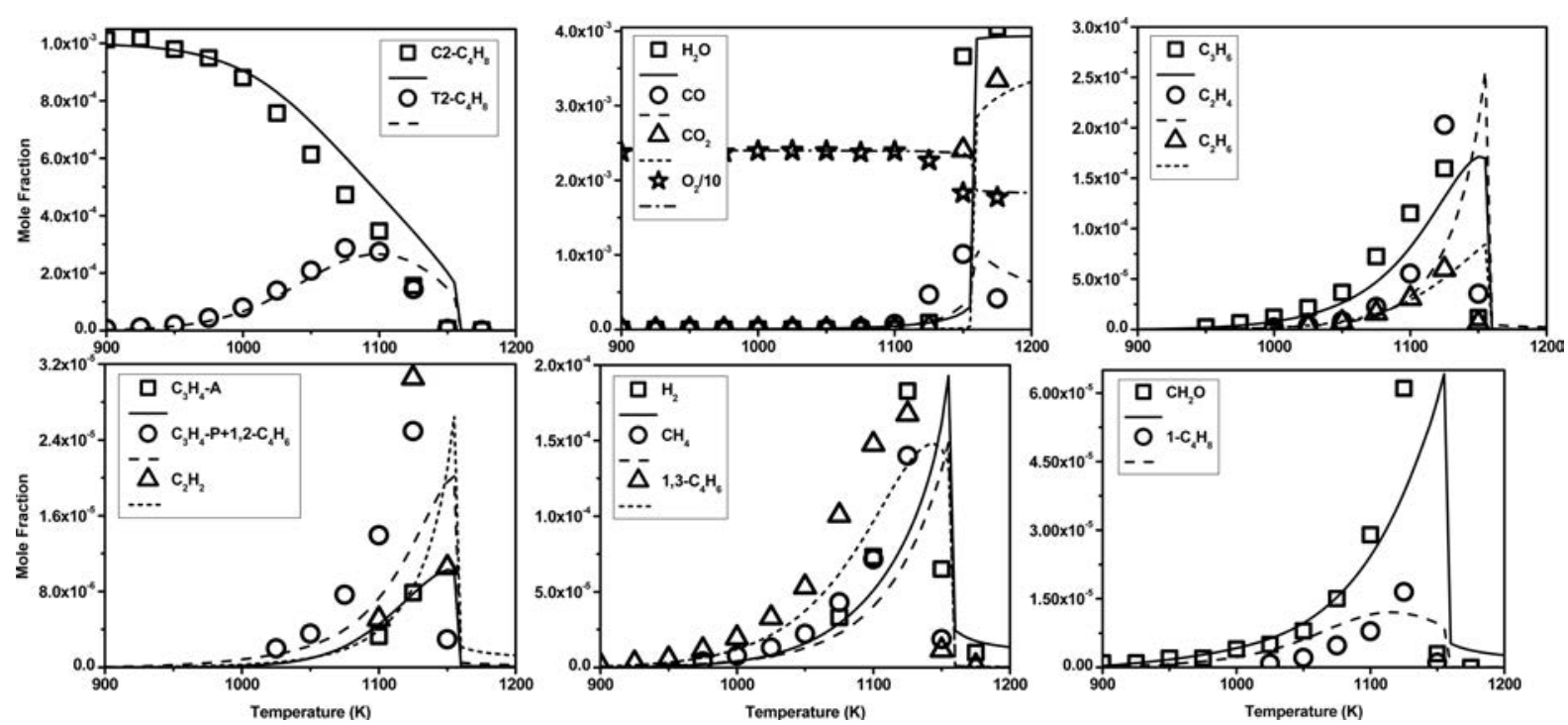

Figure 7. Experimental (symbols) and computed (lines) concentration profiles obtained from oxidation of cis-2-butene in a JSR at $\varphi=0.25, p=1$ atm, $\tau=70 \mathrm{~ms}$
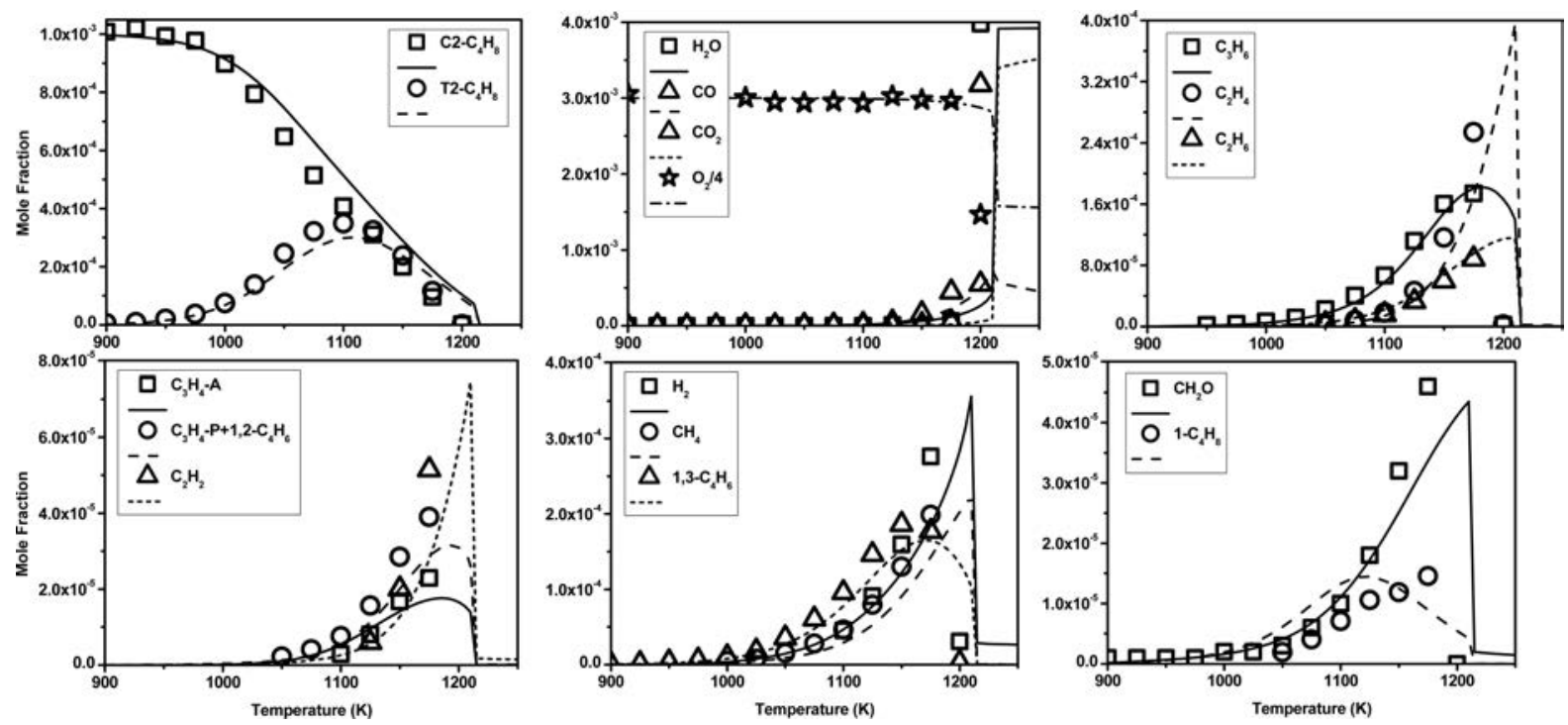

Figure 8. Experimental (symbols) and computed (lines) concentration profiles obtained from oxidation of cis-2-butene in a JSR at $\varphi=0.5, p=1$ atm, $\tau=70 \mathrm{~ms}$.

Since the oxidation of both cis- and trans-2-butene was performed in the same conditions here and in an earlier study, ${ }^{7}$ experimental concentration profiles of the fuel and two intermediates (cis-2-butene or trans-2-butene and 1,3-butadiene) were compared (Figure 12). First, the fuel concentration profiles were compared (Figure 12a). For temperatures above $1000 \mathrm{~K}$, the amount of cis-2-butene converted is higher than that of trans-2-butene. Second, between $\sim 1050$ and $1170 \mathrm{~K}$, the isomerization of the cis-2-butene fuel producing trans-2-butene is more important than the isomerization of the trans-2-butene fuel producing cis-2-butene. The fact that trans-2-butene presents a more stable structure compared to cis-2-butene explains these results. As 1,4-H elimination is considered for cis2-butene and not for trans-2-butene, higher production of 1,3butadiene would be expected from cis-2-butene oxidation. Figure $12 \mathrm{~b}$ shows that both fuels, in the same conditions, yield similar concentrations of 1,3-butadiene. From reaction pathway analyses at $1200 \mathrm{~K}$, we found that, for both fuels contributions, 1,3-butadiene is produced through $\mathrm{C}_{2} \mathrm{C}_{4} \mathrm{H}_{8} \rightleftarrows \mathrm{C}_{4} \mathrm{H}_{6}+\mathrm{H}_{2}$ with a very close rate: $43 \%$ in the case of the cis-2-butene oxidation and $39 \%$ for the trans-2-butene oxidation. Additional 1,3butadiene is produced via $\mathrm{H}$ elimination from but-1-en-3-yl radical, a radical yielded by cis- and trans-2-butene.

A first-order sensitivity analysis (Figure 13) was performed for the oxidation of cis-2-butene in a JSR at $1200 \mathrm{~K}$ to interpret the results. The sensitive branching reaction $\mathrm{H}+\mathrm{O}_{2} \rightleftarrows \mathrm{O}+$ $\mathrm{OH}$ promotes the radical pool and has an important impact on the reactivity. 1,4-H-elimination reaction $\mathrm{C}_{2} \mathrm{C}_{4} \mathrm{H}_{8} \rightleftarrows \mathrm{C}_{4} \mathrm{H}_{6}+$ $\mathrm{H}_{2}$, thermal dissociation reactions $\mathrm{T}_{2} \mathrm{C}_{4} \mathrm{H}_{8} / \mathrm{C}_{2} \mathrm{C}_{4} \mathrm{H}_{8} \rightleftarrows \mathrm{C}_{3} \mathrm{H}_{5}$-A $+\mathrm{CH}_{3}$ and $\mathrm{C}_{2} \mathrm{C}_{4} \mathrm{H}_{8}(+\mathrm{M}) \rightleftarrows \mathrm{C}_{4} \mathrm{H}_{7} 13+\mathrm{H}(+\mathrm{M})$, cis/trans isomerization reaction, and $\mathrm{H}$-abstraction reaction $\mathrm{C}_{2} \mathrm{C}_{4} \mathrm{H}_{8}+$ $\mathrm{OH} \rightleftarrows \mathrm{C}_{4} \mathrm{H}_{7} 13+\mathrm{H}_{2} \mathrm{O}$ promote the reactivity. On the contrary, reactions consuming radicals and yielding stable intermediates $\left(\mathrm{C}_{2} \mathrm{H}_{6}, \mathrm{C}_{2} \mathrm{H}_{2}\right.$, and $\left.\mathrm{C}_{3} \mathrm{H}_{6}\right)$ tend to reduce the conversion rate of cis-2-butene. 

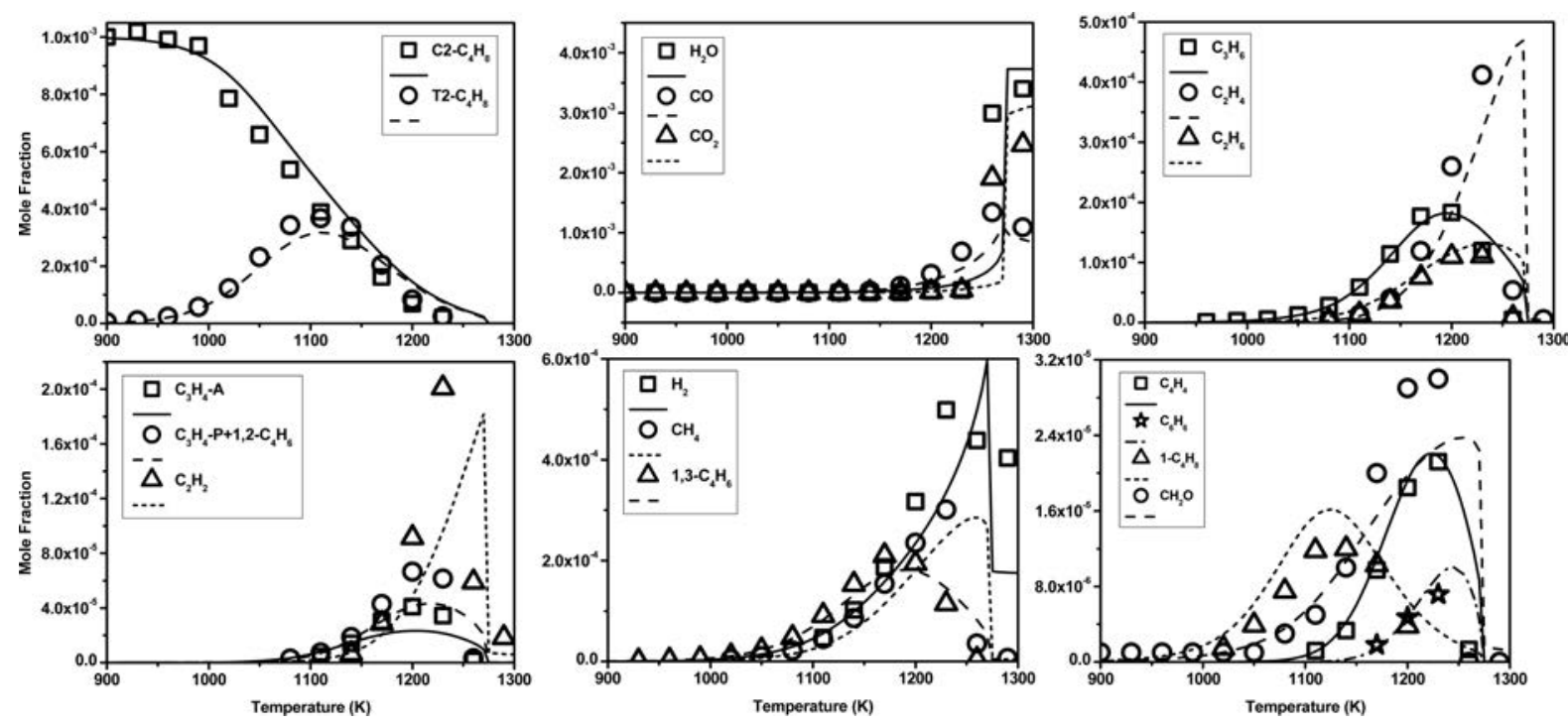

Figure 9. Experimental (symbols) and computed (lines) concentration profiles obtained from oxidation of cis-2-butene in a JSR at $\varphi=1, p=1$ atm, $\tau=70 \mathrm{~ms}$.
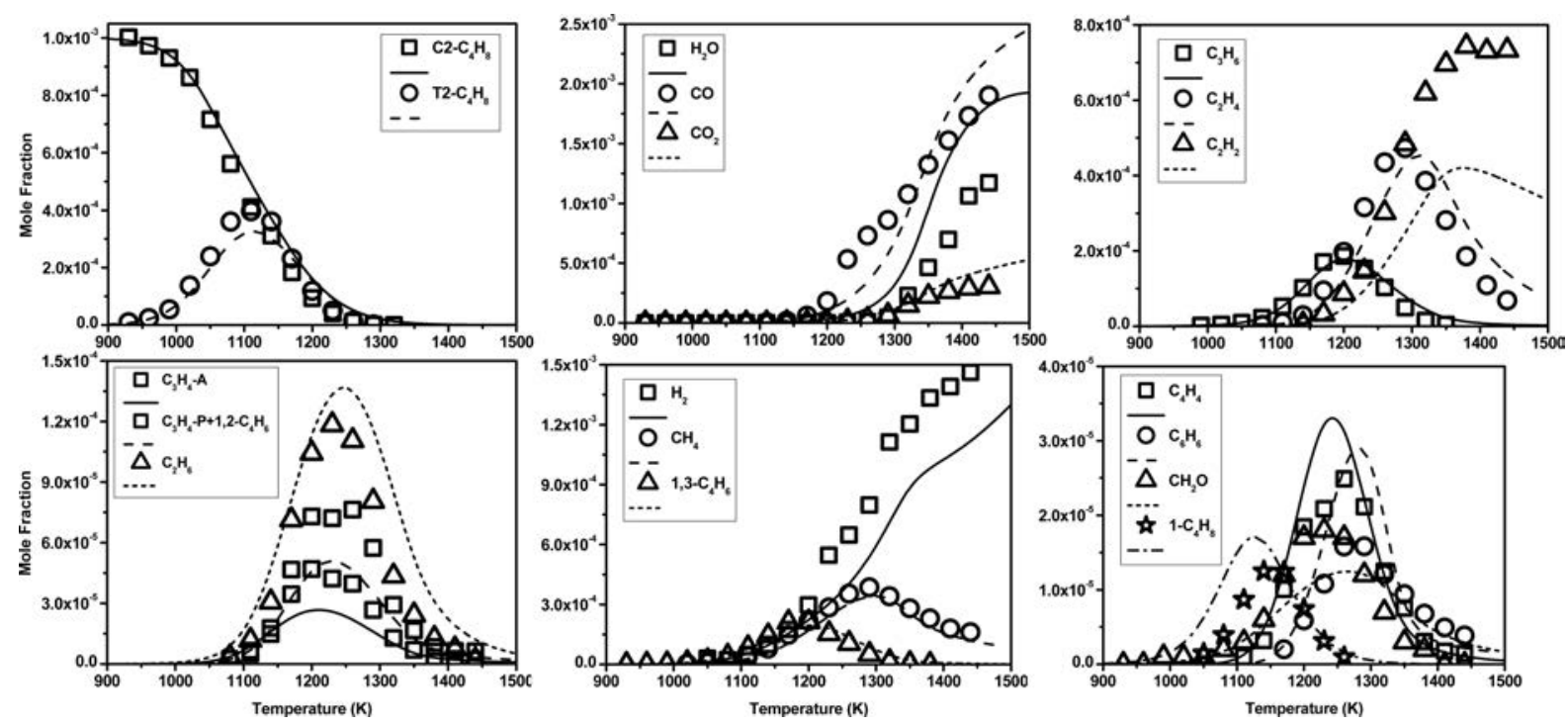

Figure 10. Experimental (symbols) and computed (lines) concentration profiles obtained from oxidation of cis-2-butene in a JSR at $\varphi=2, p=1$ atm, $\tau=70 \mathrm{~ms}$.

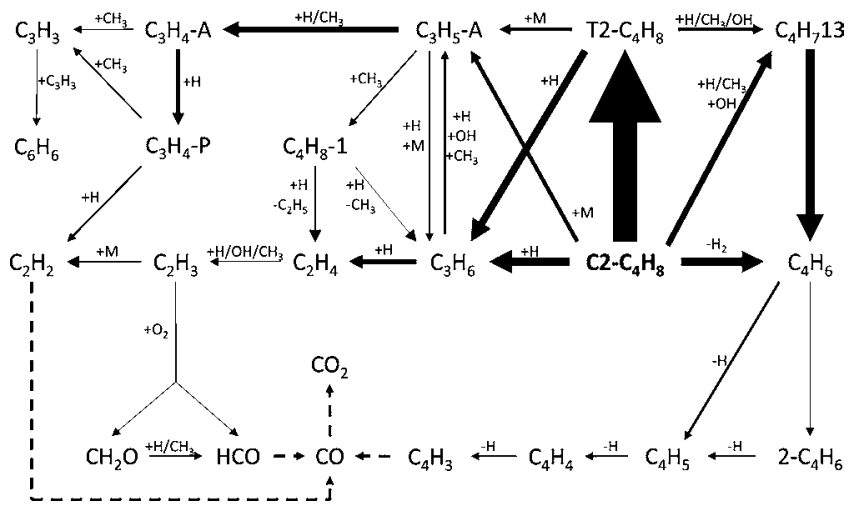

Figure 11. Reaction paths of cis-2-butene oxidation in a JSR at $\varphi=1, p$ $=1 \mathrm{~atm}, \tau=70 \mathrm{~ms}$, and $T=1200 \mathrm{~K}$.

Figure 14 illustrates the sensitivity analysis to the concentration of the allyl radical in a JSR during the oxidation of cis-2-butene at $\varphi=1$ and $T=1200 \mathrm{~K}$. Reactions involving trans-2-butene and cis-2-butene yielding propene and the allyl radical are obviously important pathways in the formation of the allyl radical. The $\mathrm{H}$-atom elimination reaction $\mathrm{C}_{3} \mathrm{H}_{5}-\mathrm{A} \rightleftarrows$ $\mathrm{C}_{3} \mathrm{H}_{4}-\mathrm{A}+\mathrm{H}$ is responsible for $56 \%$ of the conversion of the allyl radical, explaining the high sensitivity coefficient calculated. Reactions $\mathrm{C}_{2} \mathrm{C}_{4} \mathrm{H}_{8} \rightleftarrows \mathrm{C}_{4} \mathrm{H}_{6}+\mathrm{H}_{2}$ and $\mathrm{C}_{2} \mathrm{C}_{4} \mathrm{H}_{8}+\mathrm{OH} \rightleftarrows$ $\mathrm{C}_{4} \mathrm{H}_{7} 13+\mathrm{H}_{2} \mathrm{O}$ give 1,3-butadiene and $\mathrm{C}_{4} \mathrm{H}_{7} 13$. These two species, when decomposing, do not contribute to the production of allyl radicals. Therefore, the reactions producing 1,3-butadiene and $\mathrm{C}_{4} \mathrm{H}_{7} 13$ are directly in competition with reactions of 2-butenes yielding propene and the allyl radical.

This study of the oxidation of 1-butene and cis-2-butene in a JSR indicates a major production of unsaturated intermediates such as ethylene, propene, allene, and propyne. Resonance stabilized radicals such as $\mathrm{C}_{4} \mathrm{H}_{7} 13$ and $\mathrm{C}_{3} \mathrm{H}_{5}$-A show a central importance in the kinetics of oxidation of linear butenes. 


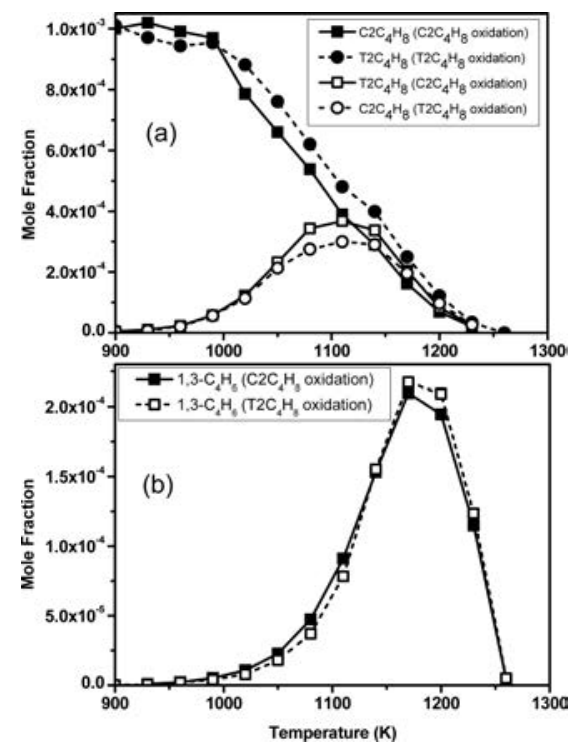

Figure 12. Experimental concentration profiles obtained from the oxidation of cis- and trans-2-butene in a JSR at $\varphi=1, \tau=70 \mathrm{~ms}$, and $p$ $=1 \mathrm{~atm}$.

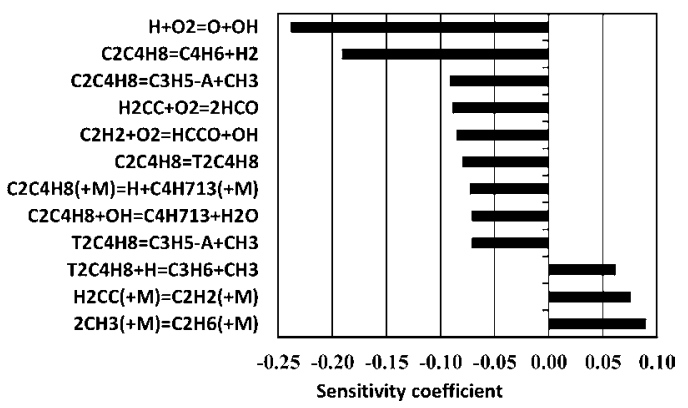

Figure 13. Sensitivity coefficients on the concentration of cis-2-butene obtained for the oxidation of cis-2-butene in a jet-stirred reactor at $\varphi=$ $1, p=1 \mathrm{~atm}, \tau=70 \mathrm{~ms}$, and $T=1200 \mathrm{~K}$. T2C $4 \mathrm{H} 8 / \mathrm{C} 2 \mathrm{C} 4 \mathrm{H} 8=$ trans $-2-$ butene/cis-2-butene; C4H6 = 1,3-butadiene; C4H713 = but-1-en-3-yl; $\mathrm{C} 3 \mathrm{H} 6$ = propene; C3H5-A = allyl radical; $\mathrm{H} 2 \mathrm{CC}=$ ethen-1,1-diyl.

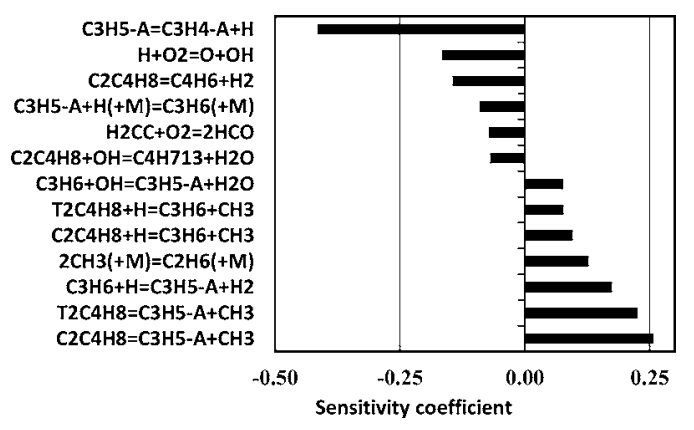

Figure 14. Sensitivity coefficients on the concentration of allyl radical obtained for the oxidation of 1-butene in a jet-stirred reactor at $\varphi=1$, $p=1 \mathrm{~atm}, \tau=70 \mathrm{~ms}$, and $T=1200 \mathrm{~K}$. T2C $4 \mathrm{H} 8 / \mathrm{C} 2 \mathrm{C} 4 \mathrm{H} 8=$ trans $-2-$ butene/cis-2-butene; $\mathrm{C} 4 \mathrm{H} 6=$ 1,3-butadiene; $\mathrm{C} 4 \mathrm{H} 713$ = but-1-en-3-yl; $\mathrm{C} 3 \mathrm{H} 6$ = propene; $\mathrm{C} 3 \mathrm{H} 5-\mathrm{A}=$ allyl radical; $\mathrm{H} 2 \mathrm{CC}=$ ethen-1,1-diyl.

4.2. Laminar Burning Velocities. Laminar burning velocities were determined based on experiments performed in a spherical combustion vessel for 1-butene/air and cis-2butene/air mixtures. Results were used to validate our kinetic mechanism. Figure 15a shows the experimental data obtained
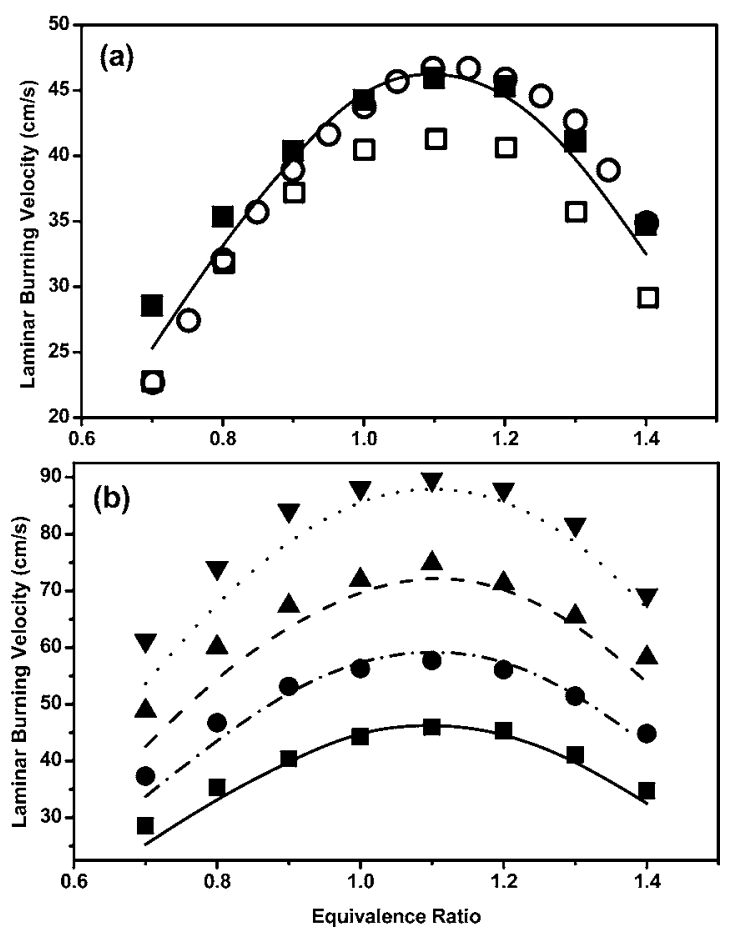

Figure 15. (a) Laminar burning velocities of 1-butene in air, $p=1 \mathrm{~atm}$, $T_{u}=300 \mathrm{~K}$. Experimental results: this work: $\mathbf{\square}$, Zhao et al.: $\square,{ }^{4}$ Davis et al.: $\mathrm{O}^{3}$ Simulation results: solid line. (b) Laminar burning velocities of 1-butene in air, $p=1 \mathrm{~atm}$. Experimental results: $T_{u}=300 \mathrm{~K}: \mathbf{\square}, T_{u}=$ $350 \mathrm{~K}: \bullet, T_{u}=400 \mathrm{~K}: \boldsymbol{\Delta}, T_{u}=450 \mathrm{~K}: \boldsymbol{\nabla}$. Simulation: $T_{u}=300 \mathrm{~K}:$ solid line, $T_{u}=350 \mathrm{~K}$ : dashed-dotted line, $T_{u}=400 \mathrm{~K}$ : dashed line, $T_{u}$ $=450 \mathrm{~K}$ : dotted line.

in this work for 1-butene/air mixtures for an unburned gases temperature of $300 \mathrm{~K}$ and are compared to the experimental data obtained in nonpremixed counter-flow burners by Zhao et al. ${ }^{4}$ The laminar burning velocities determined in this study are consistent with those obtained by Zhao et al. in the same conditions. Nevertheless, the laminar burning velocities we observed are around $5 \mathrm{~cm} / \mathrm{s}$ faster. The simulations of the laminar burning velocities obtained in these conditions with our model are coherent with the data obtained at best with an uncertainty of $\pm 2 \mathrm{~cm} / \mathrm{s}$. The maximum laminar burning velocity was measured at $45.9 \mathrm{~cm} / \mathrm{s}$ for $\varphi=1.1$; that is $4.7 \mathrm{~cm} / \mathrm{s}$ $(10 \%)$ faster than that measured by Zhao et al. ${ }^{4}$ Davis et al. ${ }^{3}$ obtained, for this equivalence ratio, a value of $46.6 \mathrm{~cm} / \mathrm{s}$ that agrees with the value we obtained. For the range of equivalence ratios we studied, the results we obtained for laminar burning velocities of 1-butene/air mixtures are similar to those reported by Davis et al. ${ }^{3}$ The model of Zhao et al. agrees with their measurements, but not with ours or those of Davis et al., which are underestimated by ca.10\% at the maximum burning velocity. The effect of increasing the temperature of the unburned gases, up to $453 \mathrm{~K}$, was also studied (Figure 15b). As expected, an increase of the temperature of the unburned gases increases the laminar burning velocities of 1-butene/air mixtures. The trend observed experimentally is accurately simulated by the model.

Laminar burning velocities of cis-2-butene/air mixtures determined in this study are plotted in Figure 16 and compared to those of Zhao et al. in the same conditions. The present experimental data are consistent with the values of Zhao et al. in fuel-lean and stoichiometric conditions, but for fuel-rich conditions, the burning velocities we obtained are slightly faster 


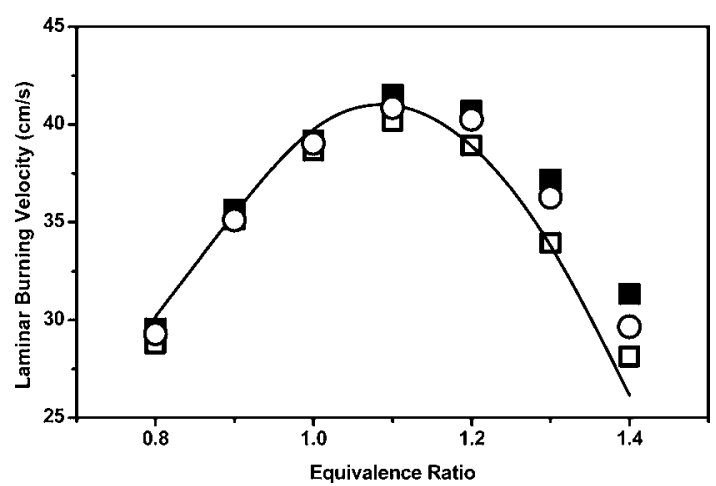

Figure 16. Laminar burning velocities of cis-2-butene in air, $p=1 \mathrm{~atm}$, $T_{u}=300 \mathrm{~K}$. Experimental results: this work: $\square$, Zhao et al.: $\square .^{4}$ Simulation results: solid line. Experimental results for laminar burning velocities of trans-2-butene/air mixtures in the same conditions: $0^{7}$

than those reported by Zhao et al. The simulation results are in good agreement with our experimental data, with a maximum burning velocity prediction at $\varphi=1.1$ of $41.5 \mathrm{~cm} / \mathrm{s}$, whereas we experimentally measured $40.8 \mathrm{~cm} / \mathrm{s}$. The model underestimates the burning velocity in fuel-rich conditions, with a maximum deviation for $\varphi=1.4$ (16\%). The burning velocities of trans-2butene/air mixtures ${ }^{7}$ are plotted in the same figure for comparison. trans-2-Butene/air mixtures demonstrate slightly lower burning velocities, compared to cis-2-butene that is evident for $\varphi>1.1$.

Figure 17 presents the laminar burning velocities for 1butene/air mixtures at constant equivalence ratio $(\varphi=0.8)$, an

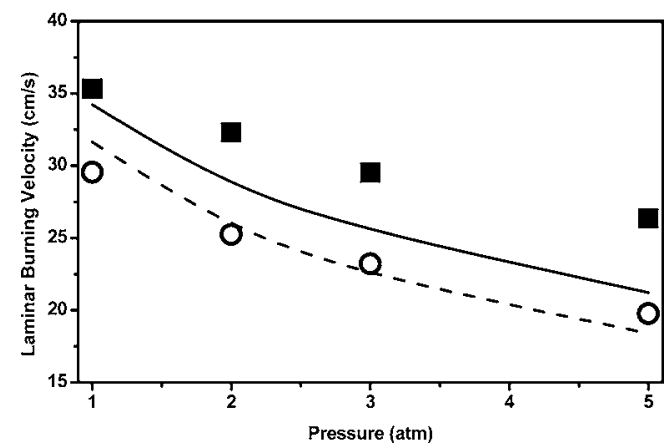

Figure 17. Laminar burning velocities of 1-butene in air (experimental data: $\mathbf{\square}$, simulation: solid line) and cis-2-butene in air (experimental data: $\bigcirc$, simulation: dashed line) at $p=1 \mathrm{~atm}, T_{u}=300 \mathrm{~K}$, and $\varphi=$ 0.8 .

unburned gases temperature of $300 \mathrm{~K}$, and pressures from 1 to $5 \mathrm{~atm}$. As the pressure increases, the laminar burning velocity decreases with a nonlinear behavior. The trend of this decrease is well captured by the simulation. However, the predicted burning velocities are underestimated for pressures between 2 and $5 \mathrm{~atm}$ for 1-butene. In Figure 17 are also plotted the burning velocities of cis-2-butene mixtures as a function of the pressure, for constant equivalence ratio $(\varphi=0.8)$, and unburned gases temperature $\left(T_{u}=300 \mathrm{~K}\right)$. The simulation is in good agreement with experiments.

4.3. Low Pressure Flame. Schenk et al. ${ }^{6}$ studied the structure of fuel-rich $(\varphi=1.7)$ butene/oxygen/argon low pressure (40 mbar) flat flames stabilized on a burner. Three isomers of butene were considered: 1-butene, trans-2-butene, and iso-butene. We used in a previous work ${ }^{7}$ Schenk's experimental data to validate our model on the oxidation of trans-2-butene. In this work, we compared the experimental data provided by Schenk et al. for a 1-butene flame (16.5\% 1$\left.\mathrm{C}_{4} \mathrm{H}_{8} / 58.5 \% \quad \mathrm{O}_{2} / 25 \% \mathrm{Ar}\right)$ to the results obtained by computation with our model. We focused on stable intermediates concentration profiles experimentally measured by molecular-beam mass spectrometry (MBMS). Comparisons are presented in Figure 18. The simulations exhibit a reliable prediction of experimental data for reactants $\left(1-\mathrm{C}_{4} \mathrm{H}_{8}\right.$ and $\left.\mathrm{O}_{2}\right)$ as well as for combustion products $\left(\mathrm{CO}, \mathrm{CO}_{2}\right.$, and $\left.\mathrm{H}_{2} \mathrm{O}\right)$. 1Butene is consumed for a distance to the burner of $0.3 \mathrm{~cm}$, and the mole fraction of final combustion products reaches a plateau of concentration above $0.6 \mathrm{~cm}$. Predicted concentration profiles of abundant intermediates such as ethylene, propene, methane, or formaldehyde are in a good agreement with experimental data. Acetylene and ethane predicted concentration profiles are acceptable. For acetylene, the computed maximum concentration is ca. $25 \%$ less than measured, and for ethane, which is a minor product, the computed maximum concentration is a factor of 2 higher than measured. Nevertheless, the simulation of $\mathrm{C}_{3} \mathrm{H}_{4}$ and $\mathrm{C}_{4} \mathrm{H}_{6}$ isomers exhibits a peak in concentration profiles that is half of the value experimentally observed. However, the position of this peak is well predicted. Through modeling, we identified the production pathways of 1,3-butadiene, the most abundant $\mathrm{C}_{4} \mathrm{H}_{6}$ isomer produced (83\% 1,3-butadiene/7\% 1,2-butadiene/4\% 1butyne/6\% 2-butyne). First, $\mathrm{H}$-atom abstraction on 1-butene yields $\mathrm{C}_{4} \mathrm{H}_{7} 13$ and $\mathrm{C}_{4} \mathrm{H}_{7} 14$, which undergo $\mathrm{H}$-atom elimination, giving 1,3-butadiene. The two isomers of $\mathrm{C}_{3} \mathrm{H}_{4}$, at the maximum of concentration ( $0.35 \mathrm{~cm}$ from the burner), allene and propyne, represent, respectively, $40 \%$ and $60 \%$ of the total amount. Allene is formed by $\mathrm{H}$-atom elimination as well as $\mathrm{H}$ abstraction from the allyl radical. Another pathway involving $\mathrm{H}$ atom addition on the propene double bond and dissociation of the adduct is responsible for allene production. Propyne is produced via isomerization of allene. Measured concentration profiles of most intermediates close to the burner are higher than computed, which could reasonably result from probeinduced perturbations. Discrepancies due to the probe effects in low pressure flame samples have been discussed by Gururajan et al. ${ }^{28}$ Helped by direct numerical simulations including the effect of the probe and supporting flange as nonadiabaticity, sampling position, and compressibility, Gururajan et al. concluded that, in the closely to realistic case, concentration profiles of species could be distorted, in the case of acetylene and ethylene, for example.

The study of the structure of 1-butene low pressure flat flames emphasizes the overriding role of resonantly stabilized radicals, such as butenyl and allyl radicals, in the kinetics of oxidation of butene.

4.4. Ignition Delays. In order to further validate our model, ignition delays were simulated in the conditions described by Heyberger et al. ${ }^{2}$ They measured autoignition delays of 1-butene/oxygen/argon mixtures behind reflected shock waves. The temperature range of their experiments was $1200-1670 \mathrm{~K}$, for pressures ranging from 6.7 to $8.9 \mathrm{~atm}$. The argon/butene/oxygen mixtures were $87 / 1 / 12 \%, 93 / 1 / 6 \%$, and $96 / 1 / 3 \%$, corresponding to the three different equivalence ratios $\varphi=0.5,1$, and 2 . The experimental ignition delays obtained by Heyberger et al. ranging from 20 to $1900 \mu \mathrm{s}$ and the present modeling results are plotted in Figure 19. The simulated ignition delay $\tau$ was defined as the time at which the rate of formation of the $\mathrm{OH}$ radical concentration $\mathrm{d}[\mathrm{OH}] / \mathrm{d} t$ is 

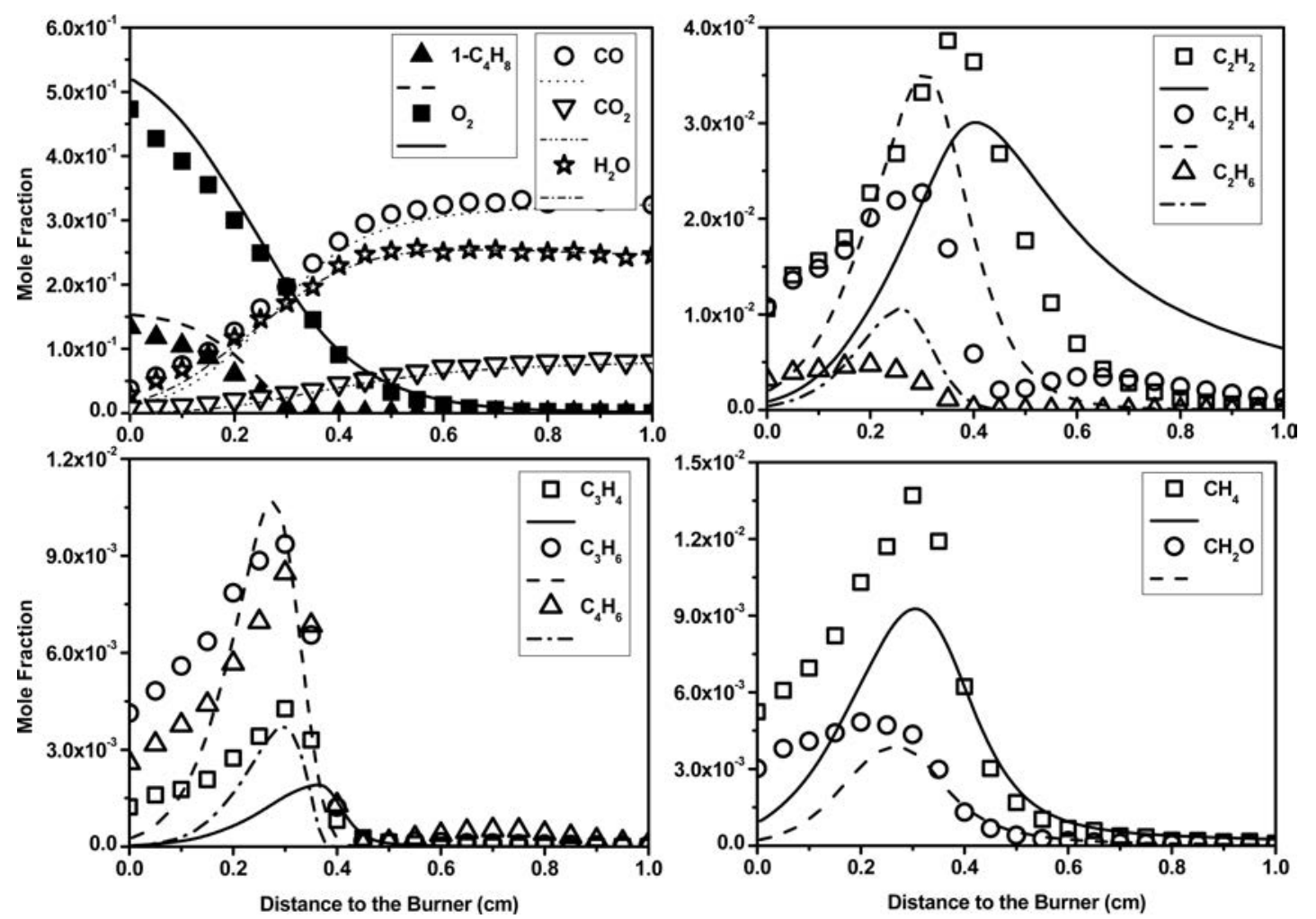

Figure 18. Experimental (symbols) and computed (lines) concentration profiles obtained from the oxidation of 1-butene in low pressure (40 mbar) flat flames $\left(16.5 \% 1-\mathrm{C}_{4} \mathrm{H}_{8} / 58.5 \% \mathrm{O}_{2} / 25 \% \mathrm{Ar}\right)$.

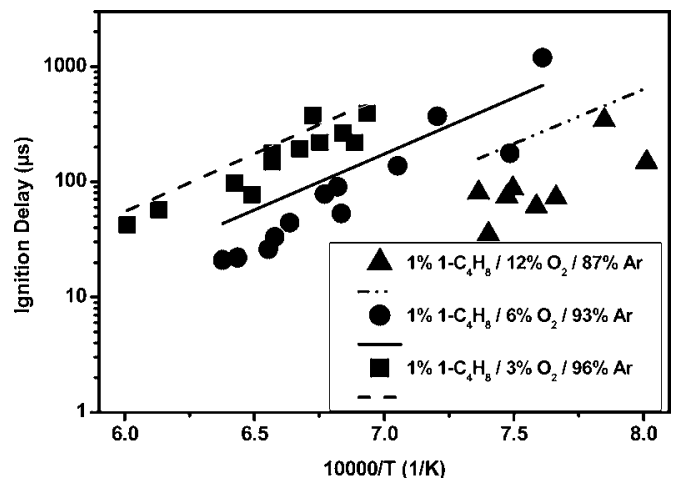

Figure 19. Experimental (symbols) and computed (lines) ignition delays obtained from the oxidation of 1-butene/oxygen/argon mixtures in a shock tube.

maximum. The agreement between experiments and simulation is acceptable. The slope of the calculated ignition delays as a function of the inverse of temperature fits the experimental data over the range of equivalence ratios considered. However, at $\varphi$ $=0.5$, the computed ignition delays seem overestimated, despite the significant scatter in the experimental data. At worst, the computations give ignition delays 2.2 times higher than those measured at $\varphi=0.5$. Sensitivity analyses indicated that the two reactions $\mathrm{C}_{4} \mathrm{H}_{8}-1(+\mathrm{M}) \rightleftarrows \mathrm{C}_{3} \mathrm{H}_{5}-\mathrm{A}+\mathrm{CH}_{3}(+\mathrm{M})$ and $\mathrm{C}_{4} \mathrm{H}_{8}-1+\mathrm{O}_{2} \rightleftarrows \mathrm{C}_{4} \mathrm{H}_{7} 13+\mathrm{HO}_{2}$ influence particularly the modeling, followed by $\mathrm{C}_{4} \mathrm{H}_{7} 13+\mathrm{H}(+\mathrm{M}) \rightleftarrows \mathrm{C}_{4} \mathrm{H}_{8}-1(+\mathrm{M})$.

\section{CONCLUSION}

In the present work, the oxidation of 1-butene and cis-2-butene was investigated in a jet-stirred reactor and a spherical combustion vessel. New experimental data were obtained for the oxidation of 1-butene and cis-2-butene in a jet-stirred reactor, at atmospheric pressure, a constant residence time of $70 \mathrm{~ms}$, for different equivalence ratios $(\varphi=0.25,0.5,1$, and 2$)$, and in the temperature range of 900-1440 K. Laminar burning velocities of 1-butene/air and cis-2-butene/air mixtures were determined over a large range of conditions using a spherical combustion chamber. At $300 \mathrm{~K}$, we varied the equivalence ratio from fuel-lean to fuel-rich; at a fixed equivalence ratio of 0.8 , the pressure was varied from 1 to 5 atm. For 1-butene, the unburned gases temperature was varied in the range of 300$450 \mathrm{~K}$. Laminar burning velocities of 1-butene were compared with data from the literature showing good agreement. Laminar burning velocity results show that 1 -butene burning velocities are higher than those of cis-2-butene, almost equal to those of trans-2-butene.

The oxidation of 1-butene and cis-2-butene in such conditions was modeled using a detailed kinetic mechanism. Good agreement with experimental data was observed. Reaction pathways and sensitivity analyses were performed to interpret the results from the JSR experiments. The modeling showed the importance of resonance stabilized radicals such as propenyl and butenyl radicals. The model was also able to represent the structure of a low pressure flat flame of 1-butene/ oxygen/argon. The predicted autoignition delays of 1-butene/ oxygen/argon mixtures obtained with this mechanism are in agreement with experimental data found in the literature. Nevertheless, discrepancies between modeling and experimental results were observed for the autoignition delays at $\varphi=0.5$. More data would help clarifying the ignition of 1-butene under fuel-lean conditions where the two reactions $\mathrm{C}_{4} \mathrm{H}_{8}-1(+\mathrm{M}) \rightleftarrows$ $\mathrm{C}_{3} \mathrm{H}_{5}-\mathrm{A}+\mathrm{CH}_{3}(+\mathrm{M})$ and $\mathrm{C}_{4} \mathrm{H}_{8}-1+\mathrm{O}_{2} \rightleftarrows \mathrm{C}_{4} \mathrm{H}_{7} 13+\mathrm{HO}_{2}$ influence particularly the modeling. This study complements a 
previous experimental and modeling study on the oxidation of trans-2-butene.

\section{AUTHOR INFORMATION}

Corresponding Author

Fax: +33 238696004. E-mail: dagaut@cnrs-orleans.fr (P.D.).

Notes

The authors declare no competing financial interest.

\section{ACKNOWLEDGMENTS}

The research leading to these results has received funding from the European Research Council under the European Community's Seventh Framework Program (FP7/20072013)/ERC grant agreement no. 291049-2G-CSafe. Y.F. thanks the European Regional Development Fund (ERDF) for a doctoral grant (contract DISPATMO).

\section{REFERENCES}

(1) Chakir, A.; Cathonnet, M.; Boettner, J. C.; Gaillard, F. Proc. Combust. Inst. 1989, 22, 873-881.

(2) Heyberger, B.; Belekki, N.; Conraud, V.; Glaude, P.-A.; Fournet, R.; Battin-Leclerc, F. Int. J. Chem. Kinet. 2002, 34, 666-677.

(3) Davis, S. G.; Law, C. K. Combust. Sci. Technol. 1998, 140, 427449.

(4) Zhao, P.; Yuan, W.; Sun, H.; Li, Y.; Kelley, A. P.; Zheng, X.; Law, C. K. Proc. Combust. Inst. 2015, 35, 309-316.

(5) Zhang, Y.; Cai, J.; Zhao, L.; Yang, J.; Jin, H.; Cheng, Z.; Li, Y.; Zhang, L.; Qi, F. Combust. Flame 2012, 159, 905-917.

(6) Schenk, M.; Leon, L.; Moshammer, K.; Oßwald, P.; Zeuch, T.; Seidel, L.; Mauss, F.; Kohse-Höinghaus, K. Combust. Flame 2013, 160, 487-503.

(7) Fenard, Y.; Dagaut, P.; Dayma, G.; Halter, F.; Foucher, F. Proc. Combust. Inst. 2015, 35, 317-324.

(8) Dagaut, P.; Cathonnet, M.; Rouan, J. P.; Foulatier, R.; Quilgars, A.; Boettner, J. C.; Gaillard, F.; James, H. J. Phys. E: Sci. Instrum. 1986, 19, 207-209.

(9) Serinyel, Z.; Togbé, C.; Zaras, A.; Dayma, G.; Dagaut, P. Proc. Combust. Inst. 2015, 35, 507-514.

(10) Galmiche, B.; Halter, F.; Foucher, F. Combust. Flame 2012, 159, 3286-3299.

(11) Kelley, A. P.; Law, C. K. Combust. Flame 2009, 156, 1844-1851.

(12) Kee, R. J.; Rupley, F. M.; Miller, J. A. Report SAND87-8215; Sandia National Laboratories: Livermore, CA, 1987.

(13) Kee, R. J.; Rupley, F. M.; Miller, J. A. Report SAND89-8009; Sandia National Laboratories: Livermore, CA, 1989.

(14) Glarborg, P.; Kee, R. J.; Grcar, J. F.; Miller, J. A. Report SAND86-8209; Sandia National Laboratories: Livermore, CA, 1986.

(15) Kee, R. J.; Grcar, J. F.; Smooke, M. D.; Miller, J. A. Report SAND85-8240; Sandia National Laboratories: Livermore, CA, 1985.

(16) Lutz, A. E.; Kee, R. J.; Miller, J. A. Report SAND87-8248; Sandia National Laboratories: Livermore, CA, 1988.

(17) Kéromnès, A.; Metcalfe, W. K.; Heufer, K. A.; Donohoe, N.; Das, A. K.; Sung, C.-J.; Herzler, J.; Naumann, C.; Griebel, P.; Mathieu, O.; Krejci, M. C.; Petersen, E. L.; Pitz, W. J.; Curran, H. J. Combust. Flame 2013, 160, 995-1011.

(18) Dagaut, P. Phys. Chem. Chem. Phys. 2002, 4, 2079-2094.

(19) Dagaut, P.; Cathonnet, M. Prog. Energy Combust. Sci. 2006, 32, 48-92.

(20) Tsang, W. J. Phys. Chem. Ref. Data 1991, 20, 221-273.
(21) Wang, H.; Dames, E.; Sirjean, B.; Sheen, D. A.; Tango, R.; Violi, A.; Lai, J. Y. W.; Egolfopoulos, F. N.; Davidson, D. F.; Hanson, R. K.; Bowman, C. T.; Law, C. K.; Tsang, W.; Cernansky, N. P.; Miller, D. L.; Lindstedt, R. P. JetSurF, version 2.0; 2010. http://melchior.usc.edu/ JetSurF/JetSurF2.0.

(22) Metcalfe, W. K.; Burke, S. M.; Ahmed, S. S.; Curran, H. J. Int. J. Chem. Kinet. 2013, 45, 638-675.

(23) Miller, J. A.; Klippenstein, S. J. J. Phys. Chem. A 2013, 117, 2718-2727.

(24) Touchard, S.; Buda, F.; Dayma, G.; Glaude, P. A.; Fournet, R.; Battin-Leclerc, F. Int. J. Chem. Kinet. 2005, 37, 451-463.

(25) Metcalfe, W.; Pitz, W. J.; Curran, H. J.; Orme, J. P.; Simmie, J. M.; Westbrook, C. K. Proc. Combust. Inst. 2007, 31, 377-384.

(26) Richard, C.; Martin, R. J. Chim. Phys. 1976, 73, 745-754.

(27) Healy, D.; Kalitan, D. M.; Aul, C. J.; Petersen, E. L.; Bourque, G.; Curran, H. J. Energy Fuels 2010, 24, 1521-1528.

(28) Gururajan, V.; Egolfopoulos, F. N.; Kohse-Höinghaus, K. Proc. Combust. Inst. 2015, 35, 821-829. 